\title{
O ICM NA IMPORTAÇÃO MEDIANTE ARRENDAMENTO MERCANTIL
}

\author{
Rafael Brum Silva \\ THE TAX ON THE CIRCULATION OF GOODS (ICM) IN IMPORTS \\ CONDUCTED BY LEASING
}

\section{RESUMO}

O PRINCIPAL OBJETIVO DESTE ESTUDO É COMPREENDER A INCIDÊNCIA do Imposto sobre CiRCulação de Mercadorias - ICM, nas OPERAÇÕES DE IMPORTAC̣ÃO, EM ESPECIAL AS REALIZADAS MEDIANTE ARRENDAMENTO MERCANTIL OU LEASING. OS ESTADOS FEDERADOS E DO DISTRITO FEDERAL SEMPRE OBJETIVARAM EFETUAR A COBRANÇA DESTE TRIBUTO SOBRE TODA E QUALQUER ENTRADA DE BENS OU MERCADORIAS IMPORTADAS DO EXTERIOR, INDEPENDENTE DA NATUREZA DO NEGÓCIO JURÍDICO EFETUADO FORA DO PAÍS. CONTUDO, ESTA PRÁtICA REALIZADA PELOS ESTADOS TEM GERADO MUITA DISCUSSÃO NO ÂMBITO DO PODER JUDICIÁRIO, ONDE OS CONTRIBUINTES TÊM SE INSURGIDO CONTRA ESTA COBRANÇA. QUASE QUE A TOTALIDADE DA DOUTRINA TEM SE POSICIONADO NO SENTIDO DE QUE O ICM SOMENTE INCIDIRÁ NA IMPORTACC̃̃O, DESDE QUE NESTA OPERAÇÃO SE CONCRETIZE A TRANSFERÊNCIA DE TITULARIDADE DO BEM OU MERCADORIA IMPORTADA DO EXTERIOR. ISTO PORQUE, O EVENTO IMPORTAÇÃO É TÃO SOMENTE UM ALARGAMENTO DA INCIDÊNCIA DO ICM, DEVENDO ESTAR VINCULADO À MATRIZ CONSTITUCIONAL DESTE TRIBUTO. HÁ TAMBÉM DE SE RESSALTAR A EXISTÊNCIA DE UM POSICIONAMENTO MINORITÁRIO DA DOUTRINA, SEGUNDO O QUAL O ICM NA IMPORTACÃO É UMA NOVA INCIDÊNCIA DO IMPOSTO, OUTORGADO AOS Estados Federados e ao Distrito Federal pelo legislador CONSTITUINTE, ADUZINDO A INCIDÊNCIA DO TRIBUTO SOBRE TODA E QUALQUER ENTRADA DE BEM OU MERCADORIA DO EXTERIOR. FRENTE A ESTE ÚLTIMO POSICIONAMENTO DA DOUTRINA É QUE OS ESTADOS SE FUNDAMENTAM PARA EFETUAR A COBRANCA DO TRIBUTO SOBRE TODA E QUALQUER OPERAÇÃO DE IMPORTAÇÃO, INDEPENDENTEMENTE DE HAVER OU NÃO A TRANSFERÊNCIA DE TITULARIDADE DO BEM OU MERCADORIA, QUANDO DA IMPORTAÇĀO. TODAVIA, OS TRIBUNAIS SUPERIORES TEM AFASTADO A COBRANÇA DESTE TRIBUTO QUANDO NAS OPERAÇÕES DE IMPORTAÇÃO NÃO OCORREM A TRANSFERÊNCIA DE TITULARIDADE DO BEM OU MERCADORIA, COMO NOS CONTRATOS DE IMPORTACÃO MEDIANTE ARRENDAMENTO MERCANTIL, OU LEASING. NESTES CONTRATOS, O BEM IMPORTADO MEDIANTE LEASING CONTINUA COMO PROPRIEDADE DO ARRENDADOR, SENDO QUE O ARRENDATÁRIO TÃO SOMENTE DETÉM A POSSE IMEDIATA DO BEM OU MERCADORIA, OU

\section{ABSTRACT}

THE MAIN PURPOSE OF THIS STUDY IS TO UNDERSTAND THE TAX INCIDENCE ON THE CIRCULATION OF GOODS (ICM) RELATED TO IMPORTS, PARTICULARLY THOSE CONDUCTED BY LEASING. THE FEDERATED STATES AND THE FEDERAL DISTRICT HAVE ALWAYS AIMED TO MAKE THE TAXES COLLECTION OF ANY IMPORTED GOODS, REGARDLESS OF THE LEGAL BUSINESS NATURE DONE OUTSIDE THE COUNTRY. HOWEVER, THESE STATES' PRACTICE HAS GENERATED A DISCUSSION IN THE JUDICIARY, AS THE TAXPAYERS HAVE PROTESTED AGAINST THESE CHARGES. ALMOST ALL THE DOCTRINE BELIEVES THAT ICM WILL JUST FOCUS ON IMPORTATION - BUT ONLY IF IN THIS OPERATION THE IMPORTED GOODS OWNERSHIP TRANSFERENCE TAKES PLACE. THIS UNDERSTANDING IS BASED ON THE FACT THAT THE IMPORTATION IS ONLY AN ICM IMPACT EXTENSION. FOR THIS REASON, IT SHOULD BE BOUNDED TO THE CONSTITUTIONAL LAW OF THIS TAX. IT IS ALSO IMPORTANT TO EMPHASIZE THE EXISTENCE OF A MINORITY DOCTRINE POSITION, WHICH BELIEVES THAT THE ICM OF IMPORTATION IS A NEW INCIDENCE OF TAX (ICM), GRANTED TO THE FEDERAL STATES AND THE FEDERAL DISTRICT BY THE CONSTITUTIONAL LEGISLATOR, ADDING THE IMPACT OF TAXES ON ANY AND ALL INPUT OF GOODS FROM ABROAD. DUE TO THIS POSITIONING OF THE DOCTRINE IS THAT STATES HAVE THE LEGAL SUPPORT TO MAKE THE COLLECTION OF TAX ON ANY IMPORT TRANSACTION, REGARDLESS OF WHETHER OR NOT THERE IS TRANSFER OF OWNERSHIP OF THE GOODS UPON IMPORTATION. HOWEVER, THE SUPREME COURT HAS DISMISSED THE COLLECTION OF THE TAX WHEN IN THE IMPORT OPERATIONS DO NOT OCCUR A TRANSFER OF OWNERSHIP OF THE PROPERTY, AS IN CONTRACTS FOR IMPORTS THROUGH LEASING. IN THESE CONTRACTS, THE PRODUCTS IMPORTED BY LEASING REMAIN WITHIN THE PROPERTY OF THE LESSOR, AND THE LESSEE ONLY HAS THE IMMEDIATE POSSESSION OF THE PROPERTY. IN OTHER WORDS, IN THESE OPERATIONS 
SEJA, SÃO OPERAÇÕES EM QUE NÃO OCORRE A TRANSFERÊNCIA DA TITULARIDADE DO PRODUTO, NÃO HAVENDO INCIDÊNCIA DO ICM NESTAS OPERAÇÕES DE IMPORTAÇÃO.

PALAVRAS-CHAVE

DIREITO TRIBUTÁRIO; ICM; IMPORTAÇÃO; ARRENDAMENTO MERCANTIL; LEASING.
THE TRANSFER OF OWNERSHIP OF THE PROPERTY DOES NOT OCCUR, CONSEQUENTLY, THERE ISN'T THE INCIDENCE OF ICM IN THESE OPERATIONS.

\section{KEYWORDS}

tAX LAW; TAX on the CiRCulation of GOOdS; IMPORT; LEASING.

\section{INTRODUÇÃO}

O presente trabalho tem como objetivo principal demonstrar e compreender a cobrança e, especificamente, a incidência do Imposto sobre Circulação de Mercadorias - ICM nas operações de importação, em especial as realizadas mediante arrendamento mercantil, ou leasing, como é usualmente denominado na prática empresarial.

A importância do tema se justifica na clara tendência dos Estados Federados e do Distrito Federal, em efetuar a cobrança do ICM sobre toda e qualquer entrada de bens ou mercadorias importadas do exterior, independente da natureza do negócio jurídico entabulado fora do país.

Nesse aspecto, a análise da incidência do ICM nas importações terá como objetivo compreender a real extensão do tributo nestas operações, destacando-se o estudo da norma jurídica tributária do imposto, prevista na Constituição Federal de 1988, em seu artigo 155 , inciso II, $\S 2^{\circ}$, IX, alínea $a$.

Para tanto, em um primeiro momento, efetuar-se-á uma análise da regra matriz de incidência fiscal do ICM, demonstrando todos os elementos que a compõem, dandose maior ênfase ao critério material de sua hipótese tributária, o qual é de fundamental importância para se compreender a incidência do tributo no presente caso.

Em seguida, frente à regra matriz constitucional do ICM, voltar-se-á o estudo, especificamente, para as operações de importação. Neste aspecto, será realizada uma análise dos posicionamentos principais da doutrina sobre o tema, a fim de identificar se o ICM na importação é uma nova incidência do imposto, outorgado aos Estados Federados e ao Distrito Federal pelo legislador constituinte, ou ainda, se o evento importação é tão somente um alargamento da incidência do ICM, devendo estar vinculado à matriz constitucional deste tributo.

Com a identificação da forma de incidência do ICM nas operações de importação, será possível compreender a incidência deste tributo nas entradas de bens ou mercadorias do exterior, realizadas mediante arrendamento mercantil ou leasing. Para isso, no presente trabalho, será imprescindível o estudo das operações de arrendamento mercantil ou leasing, frente ao direito empresarial, bem como o direito do comércio exterior.

E, por fim, após a verificação de como ocorre a incidência do ICM nas operações de importação mediante arrendamento mercantil ou leasing, será estudado o entendimento dos Tribunais Superiores sobre a matéria. Neste ponto, destaca-se a 
jurisprudência do Supremo Tribunal Federal, que em recentes julgados analisou a incidência deste tributo nas operações de importação efetuadas por meio do arrendamento mercantil ou leasing.

\section{REGRA MATRIZ DE INCIDÊNCIA FISCAL DO ICM}

Antes de se aprofundar na apresentação da regra matriz de incidência fiscal do Imposto sobre a Circulação de Mercadorias (ICM), estudo imperativo para se compreender a cobrança e, especificamente, a incidência deste tributo nas operações de importação, com destaque para as realizadas mediante arrendamento mercantil, faz-se necessário um estudo do que seja a regra matriz de incidência fiscal.

Para elucidar o estudo necessário dizer que a regra matriz de incidência fiscal é uma concepção doutrinária de Professor Doutor Paulo de Barros Carvalho, apresentada em sua tese de Doutoramento, reproduzida na sua obra Teoria da Norma Tributária, de 1974. Neste estudo, utilizando-se da filosofia jurídica e da teoria geral do direito, seguindo a doutrina neopositivista de Norberto Bobbio, e sua análise linguística da ciência do direito, aplicada sobre o prisma da teoria da linguagem de Jürgen Habermas, o Professor Paulo de Barros Carvalho descreveu os preceitos a serem observados para que o fenômeno da incidência da norma jurídica tributária se concretize em determinado evento passível de tributação, propagando seus efeitos no universo do direito.

Segundo a doutrina de Norberto Bobbio, elucidada através de suas obras Teoria da norma jurídica (1958) e Teoria do ordenamento jurídico (1960), existem dois tipos de normas em um ordenamento jurídico: as normas de conduta, que são voltadas para as condutas e os comportamentos das pessoas, nas suas relações intersubjetivas. Para o autor:

A nossa vida se desenvolve em um mundo de normas. Acreditamos ser livres, mas na realidade, estamos envoltos em uma rede muito espessa de regras de conduta que, desde o nascimento até a morte, dirigem nesta ou naquela direção as nossas ações. ${ }^{2}$

Além das normas de conduta citadas acima, Bobbio descreveu, ainda, a existência das normas de estrutura, que dispõem de que maneira as normas devem ser criadas, transformadas ou expulsas do ordenamento jurídico. Nas palavras do próprio autor:

Em todo o ordenamento, ao lado das normas de conduta, existe um outro tipo de normas, que costumamos chamar de normas de estrutura ou de competência. São aquelas normas que não prescrevem a conduta que se deve ter ou não ter, mas as condições e os procedimentos através dos quais emanam normas de conduta válidas. ${ }^{3}$ 
Utilizando-se desse aspecto, Carvalho ${ }^{4}$ conceitua a regra matriz de incidência fiscal como sendo uma norma de conduta, que disciplina o comportamento do sujeito devedor da prestação fiscal, perante o sujeito credor, titular do direito de crédito.

Vale dizer que a norma jurídica tributária, como todas as outras normas de conduta do ordenamento jurídico, prescreve um mandamento geral e abstrato de determinado evento do universo dos fatos. Este evento, passível de tributação, o autor denomina de hipótese tributária, a qual, concretizando-se no campo das realidades materiais, torna-se uma norma concreta e individual, e o evento, antes apenas uma hipótese, um fato jurídico tributário que irradiará efeitos no universo jurídico. ${ }^{5}$

Neste ponto, deve-se esclarecer que a propagação destes efeitos não ocorre com a simples concretização de um evento previsto em uma norma jurídica. Tal fato não é suficiente para gerar efeitos no mundo do direito. $\mathrm{O}$ evento ocorrido no mundo das realidades materiais deve ser de conhecimento do universo jurídico para que tal concretização possa irradiar os efeitos pretendidos pela norma jurídica. Nesse aspecto, conforme preleciona o autor, utilizando-se a Teoria da Linguagem de Jürgen Habermas, o mundo do direito apenas pode ter conhecimento do evento ocorrido no mundo dos fatos através de uma linguagem competente, ${ }^{6}$ a qual, no campo do direito tributário, ocorre através do lançamento tributário.

Feita esta ressalva, relevante expor a conceituação de hipótese tributária elaborada pelo Professor Geraldo Ataliba, que prefere denominar hipótese de incidência (h.i.):

A h.i., é primeiramente a descrição legal de um fato: é a formulação hipotética, prévia e genérica, contida na lei, de um fato (é o espelho do fato, a imagem conceitual de um fato; é seu desenho).

É, portanto, mero conceito, necessariamente abstrato. É formulado pelo legislador fazendo abstração de qualquer fato concreto. Por isso é mera "previsão legal” (a lei é, por definição, abstrata, impessoal e geral). ${ }^{7}$

Na sequência, Ataliba também conceitua fato jurídico tributário, o que denomina de fato imponível:

A lei (h.i) descreve hipoteticamente certos fatos, estabelecendo a consistência de sua materialidade. Ocorridos concretamente estes fatos hic et nunc, com a consistência prevista na lei e revestindo de forma prefigurada idealmente na imagem legislativa abstrata, reconhece-se que desses fatos nascem obrigações tributárias concretas. A esses fatos, a cada qual, designamos "fato imponível (ou fato tributário). ${ }^{8}$

Importante destacar que o evento do mundo dos fatos descrito na norma jurídica tributária de forma geral e abstrata (hipótese tributária), passível de tributação, 
possui várias denominações, assim como a concretização do evento previsto na norma (fato jurídico tributário). Varia-se a denominação conforme a preferência de cada doutrinador. Muitas vezes a hipótese tributária é denominada de situação-base, pressuposto de fato tributário, suporte fático, hipótese de incidência, fato gerador, etc. Contudo, no presente estudo, seguindo o pensamento do professor Paulo de Barros Carvalho, na obra Teoria da norma tributária, optou-se pela denominação de hipótese tributária, pois esta constitui a expressão que melhor conceitua o evento previsto na norma jurídica tributária. Da mesma forma, seguindo o pensamento do mesmo autor, no presente estudo adota-se a denominação fato jurídico tributário, para descrever a concretização do evento previsto na norma como um acontecimento da realidade material.

Feita a observação, pode-se dizer, em apertada síntese, que, o evento geral e abstrato, previsto na norma jurídica tributária (hipótese tributária), concretizando-se como um acontecimento no mundo das realidades materiais, através de linguagem competente, torna-se um fato jurídico tributário.

O fato jurídico tributário, no entanto, para que venha nascer é preciso que ocorra a chamada subsunção do fato a norma, ou seja, é necessário que o evento passível de tributação ocorra de modo a se adequar perfeitamente ao descrito na hipótese da norma jurídica tributária, satisfazendo todos os critérios impostos pela norma jurídica. Ataliba ensina que:

Subsunção é o fenômeno de um fato configurar rigorosamente a previsão hipotética da lei. Diz-se que um fato se subsume à hipótese legal quando corresponde completa e rigorosamente à descrição que dele faz a lei. ${ }^{9}$

Para Carvalho:

É aquilo que se tem por tipicidade, que no Direito Tributário, assim como no Direito Penal, adquire transcendental importância. Para que seja tido como fato jurídico tributário, a ocorrência da vida real, descrita no suposto da norma individual e concreta expedida pelo órgão competente, tem de satisfazer a todos os critérios identificadores tipificados na hipótese da norma geral e abstrata. Que apenas um não seja reconhecido, e a dinâmica que descrevemos ficará inteiramente comprometida. ${ }^{10}$

Seguindo este raciocínio, para que nasça o fato jurídico tributário, o evento passível de tributação, o qual é descrito na norma jurídica tributária, no momento de sua ocorrência no mundo das realidades materiais, deverá preencher todos os critérios da hipótese tributária prescrita na norma. Carvalho destaca a importância dos critérios que compõem a hipótese tributária: 
Daí dizermos que as hipóteses são conjuntos de critérios que nos permitem identificar fatos do universo físico, o que vale a afirmar, com o mesmo significado, que se trata da descrição legal de eventos da realidade tangível. [...]

O conceito que se contém na hipótese haverá de representar o acontecimento de um fato, mediante o oferecimento de critérios que nos permitam identificá-lo. Para tanto, é mister sabermos de sua estrutura central, bem como das circunstâncias de espaço e de tempo que haverão de condicionar seu nascimento. ${ }^{11}$

Neste ponto, importante destacar os critérios mencionados por esse autor, os quais compõem a hipótese tributária, haja vista serem essenciais para a configuração dos fatos jurídicos tributários.

Tais critérios são divididos em: critério material, critério espacial e critério temporal. O critério material é a "estrutura central”, o núcleo da norma jurídica tributária. Nele encontra-se descrito um comportamento de pessoas, físicas ou jurídicas, que o legislador importa relevância em fazer incidir a tributação, devendo ser estudado de forma separada dos critérios espaciais e temporais, a fim de se abstrair sua essência de modo particular, para que se possa compreender, de fato, qual é o comportamento dos indivíduos que a norma jurídica tributária pretende incidir os seus efeitos. ${ }^{12}$

Segundo o mesmo doutrinador, o critério material deve ser composto de "expressões genéricas designativas de comportamento de pessoas, sejam aquelas que encerram um fazer, um dar ou, simplesmente, um ser (estado)". ${ }^{13}$ Dessas expressões, têm-se como exemplos: "vender mercadorias", "industrializar produtos", "ser proprietário de bem imóvel”, "auferir rendas”, etc.

Todas as expressões acima mencionadas são compostas por um verbo que designa uma ação (vender, industrializar, ser, auferir), acompanhados de um complemento (mercadorias, produtos, proprietário de bem imóvel, renda). Portanto, a presença do verbo e o seu complemento é de fundamental importância para a configuração do critério material da hipótese tributária, isto porque possibilitará a observância do comportamento no mundo da realidade material que a norma jurídica tributária pretende fazer incidir o tributo. ${ }^{14}$

Nesse sentido, Ataliba menciona que o critério material “dá, por assim dizer, a verdadeira consistência da hipótese de incidência”, pois, "contém a indicação de sua substância essencial, que é o que de mais importante e decisivo há na sua configuração". ${ }^{15}$

Quanto ao critério espacial, este se refere ao lugar em que o evento passível de tributação, descrito na norma jurídica tributária de forma geral e abstrata, deve concretizar-se no mundo as realidades materiais, para que esta, a norma jurídica tributária, irradie os seus efeitos jurídicos. 
De forma mais simplificada, pode-se dizer que o critério espacial possibilita a identificação do local onde o critério material deve ocorrer para que a norma jurídica tributária venha gerar seus efeitos.

Nas palavras de Carvalho, através do critério espacial "se precisam os elementos necessários e suficientes para identificarmos a circunstância e lugar que condiciona o acontecimento do fato jurídico". ${ }^{16}$ Este autor ainda esclarece:

A descrição normativa não fixa lugares exclusivos, não se detendo por oferecer um rol limitado de postos. Antes, prevê áreas, regiões, intervalos territoriais, extensos e dilatados, dentro dos quais, em qualquer de seus pontos, pode efetivar o evento. ${ }^{17}$

Vale mencionar que o critério espacial não pode ser confundido com o campo de validade territorial da norma jurídica tributária. Ou seja, não é só porque a norma jurídica tributária detém aplicação em um determinado território que o critério espacial incidirá na integralidade desse campo de aplicação da norma jurídica tributária. Como exemplo, pode-se mencionar o Imposto sobre a propriedade Territorial Rural (ITR), norma de aplicação em âmbito nacional, contudo, que incidirá apenas sobre os territórios rurais, excluindo-se sua aplicação no território urbano.

E, por fim, tem-se o critério temporal, que pode ser definido como o grupo de informações contidas na hipótese tributária, as quais possibilitam a verificação do exato instante em que ocorre o evento, geral e abstrato, previsto na norma jurídica tributária. Mais precisamente, é o conjunto de elementos da hipótese tributária que permite a identificação do instante em que ocorre o seu critério material. ${ }^{18}$

Carvalho assim define o critério temporal:

Compreendemos o critério temporal da hipótese tributária como o grupo de indicações, contidas no suposto da regra, e que nos oferecem elementos para saber, com exatidão, em que preciso instante acontece o fato descrito [...]. ${ }^{19}$

Muitas vezes o legislador seleciona uma data como identificador do momento exato de ocorrência do evento previsto na norma jurídica tributaria. Já em outras, prefere selecionar o instante em que o próprio evento ocorre, ou seja, o momento em que se dá a ocorrência do critério material previsto na hipótese tributaria. Contudo, segundo Ataliba, o critério temporal também poderá estar implícito na norma jurídica tributária. ${ }^{20}$

Feitas estas observações quanto aos critérios que compõem a hipótese tributária prevista na norma jurídica tributária, passa-se à análise dos efeitos que são propagados após a ocorrência dos critérios da hipótese tributária no universo das realidades materiais, ou seja, após a subsunção do fato à norma, que se falou anteriormente. 
Continuando o raciocínio lógico até aqui despendido, tem-se que, no instante em que a hipótese tributária se concretiza no mundo das realidades materiais, ou seja, mais precisamente, no momento em que o critério material, previsto na hipótese tributária, um evento descrito de forma geral e abstrata, efetiva-se no campo físico, no local e no exato instante previsto na hipótese tributária (critério espacial e temporal, respectivamente), esta norma, antes geral e abstrata, está apta a, através de uma linguagem competente, tornar-se uma norma concreta e individual, fazendo nascer o fato jurídico tributário, o qual irradiará efeitos da norma no mundo jurídico.

Buscando a conceituação no direito civil (teoria geral do direito), pode-se afirmar que os fatos jurídicos, na conceituação de Francisco Amaral, são acontecimentos que produzem efeitos jurídicos, causando o nascimento, a modificação ou a extinção de relações jurídicas e de seus direitos. ${ }^{21}$ Por relação jurídica deve se entender como o vínculo que o direito estabelece entre pessoas ou grupos, atribuindo-lhes poderes e deveres.

O mesmo, por óbvio, ocorre no direito tributário, onde a norma jurídica tributária faz nascer direitos e deveres para as pessoas envolvidas com o acontecimento previsto na hipótese tributária, ligando tais pessoas por um vínculo jurídico, ou seja, uma relação jurídica tributária.

Para Carvalho, os efeitos gerados pela concretização do fato jurídico tributário, qual seja, o nascimento de uma relação jurídica tributária é o consequente lógico previsto na norma jurídica tributaria, o qual também deve ser identificado através de critérios estabelecidos na própria norma jurídica tributária. Nos ensinamentos do professor:

Se a hipótese, funcionando como descritor, anuncia os critérios conceptuais para o reconhecimento de um fato, o conseqüente, como prescritor, nos dá, também, critérios para a identificação do vínculo jurídico que nasce, facultando-nos saber quem é o sujeito portador do direito subjetivo; a quem foi cometido o dever jurídico de cumprir certa prestação; e seu objeto, vale dizer, o comportamento que a ordem jurídica espera do sujeito passivo e que satisfaz, a um só tempo, o dever que lhe fora atribuído e o direito subjetivo de que era titular o sujeito pretensor. ${ }^{22}$

Os critérios estabelecidos na norma jurídica tributária são divididos em critério pessoal e critério quantitativo, tendo singular importância na identificação da relação jurídica tributária surgida pela ocorrência da hipótese tributária no campo físico.

Através do critério pessoal podem se identificar os sujeitos de direito que fazem parte da relação jurídica nascida pela concretização da hipótese tributária no universo real, ou seja, os sujeitos que integram o vinculo jurídico. Tais sujeitos são divididos em: sujeito ativo e sujeito passivo.

Entende-se por sujeito ativo aquele que é titular do direito subjetivo, consistente em exigir determinada prestação pecuniária. É o credor ou pretensor que exigirá o 
pagamento do crédito tributário, ou seja, o cumprimento da obrigação tributária nascida pela concretização da hipótese tributária. Esta pessoa, de modo geral, é o Estado, entendido no seu sentido lato. No ordenamento jurídico pátrio, o sujeito ativo pode ser identificado, ainda que não ocorra a concretização da hipótese tributária no mundo das realidades materiais. Isso, pois, a constituição federal designa, na maioria das vezes explicitamente, quem é o titular do direito subjetivo de exigir a prestação pecuniária. Ou seja, quando a norma estabelece quem é competente para criar determinado tipo de tributo. ${ }^{23}$

No conceito de Ataliba:

Sujeito ativo é o credor da obrigação tributária. É a pessoa aquém a lei atribui a exigibilidade do tributo. Só a lei pode designar o sujeito ativo. Essa designação compõe a h.i., integrando seu aspecto pessoal. ${ }^{24}$

De outro norte, o sujeito passivo da relação jurídica tributária é a pessoa de quem será exigido o cumprimento da prestação pecuniária. Tal pessoa pode ser física ou jurídica, de direito privado ou de direito público. É o devedor da prestação fiscal. É aquela que tem o dever de pagar o tributo, sendo denominada, via de regra, contribuinte. ${ }^{25}$

Nos ensinamentos de Ataliba, "é sujeito passivo, em regra, uma pessoa que está em conexão íntima (relação de fato) com o núcleo (aspecto material) da hipótese de incidência”. ${ }^{26}$ Nesse aspecto, pode-se dizer que sujeito passivo é aquele que concorre, de alguma formar, para a concretização da hipótese tributária no universo das realidades materiais, sendo este de quem será exigido o cumprimento da prestação pecuniária.

O segundo critério previsto na norma jurídica tributária como parâmetro para o surgimento a relação jurídica tributária é o critério quantitativo. Através deste critério pode se identificar qual o objeto desta relação jurídica. No campo tributário este objeto é o cumprimento de uma prestação pecuniária, o pagamento do tributo.

Com efeito, deve poder-se identificar o quantum o sujeito passivo deverá pagar de tributo. Nesse aspecto, a norma jurídica tributária deve proporcionar ao intérprete as condições para a fixação do montante a ser pago pelo devedor, in casu, o contribuinte. Este montante a ser pago é fixado pela norma jurídica tributária através de dois elementos: base de cálculo e alíquota. ${ }^{27}$

A base de cálculo é definida como sendo uma grandeza que se destina a dimensionar a intensidade do comportamento prescrito no núcleo (critério material) da hipótese tributária. ${ }^{28}$ Ou seja, é a grandeza, atrelada intimamente ao critério material da hipótese tributária, que a norma jurídica tributária elege para auferir o valor do tributo a ser pago pelo sujeito passivo.

Ataliba assim conceitua a base de cálculo, que ele denomina de base imponível: 
Base imponível é uma perspectiva dimensível do aspecto material da h.i. que a lei qualifica, com a finalidade de fixar critério para a determinação, em cada obrigação tributária concreta, do quantum debetur. ${ }^{29}$

A alíquota, por sua vez, é o fator que deve ser aplicado sobre esta grandeza (base de cálculo), a fim de se auferir o montante de tributo que o sujeito passivo deverá pagar, e, por conseguinte, o quantum poderá ser exigido pelo sujeito ativo da relação jurídica tributária. ${ }^{30}$

Nesse aspecto, pode-se dizer que a alíquota é um elemento auxiliar para se estabelecer o quantum tributário, ou seja, o montante do valor do tributo a ser pago pelo sujeito passivo para o sujeito ativo da relação jurídica tributária.

$\mathrm{Na}$ conceituação de Ataliba:

A alíquota é um termo do mandamento da norma tributária, mandamento esse que incide se e quando se consuma o fato imponível, dando nascimento à obrigação tributária concreta.

Deve receber a designação de alíquota só esse termo que se consubstancia na fixação de um critério indicativo de uma parte, fração - sob a forma de percentual, ou outra - da base imponível. ${ }^{31}$

Mister a presença destes elementos que compõem o critério pessoal e quantitativo para que nasça uma relação jurídica tributária apta a propagar seus efeitos no mundo do direito.

Diante do exposto, pode-se afirmar que para a ocorrência do fenômeno da incidência da norma jurídica tributária em determinado evento passível de tributação, é imprescindível que os critérios prescritos pela regra matriz de incidência fiscal sejam configurados. Apenas diante da constatação destes critérios é que ocorre a propagação dos efeitos da norma jurídica tributária, dando ensejo ao nascimento da obrigação tributária, ou seja, do dever de pagamento do tributo.

Em breve síntese, para que exista o dever de pagamento do tributo é necessário que a norma jurídica tributária apresente todos os critérios exigidos pela regra matriz de incidência fiscal. Nesse aspecto, o evento do mundo dos fatos, descrito na norma jurídica tributária, de forma geral e abstrata (hipótese tributária), concretizando-se no mundo das realidades materiais, deve observar os critérios previstos na norma jurídica tributária (critério material, espacial e temporal), para, através de uma linguagem competente, tornar-se uma norma concreta e individual, dando origem ao fato jurídico tributário. Este fato, por óbvio, irradiará efeitos no mundo jurídico, fazendo nascer a relação jurídica tributária, que também deverá ser composta, obrigatoriamente, pelos critérios previstos na norma jurídica tributária (critério pessoal e critério quantitativo). Somente com o fechamento completo deste ciclo é que ocorre a incidência da norma 
jurídica tributária apta ao surgimento de uma obrigação jurídica tributária, ou seja, ao dever de pagamento da prestação fiscal (pagamento do tributo).

Feitas estas considerações e explanações quanto à regra matriz de incidência fiscal, passa-se ao estudo da regra matriz de incidência fiscal especificamente do Imposto sobre a Circulação de Mercadorias (ICM).

Vale ressaltar que este estudo será abordado de forma abrangente, somente para fins de fixação e entendimento geral da regra matriz de incidência fiscal deste tributo. Somente o critério material será analisado com maior ênfase, haja vista sua fundamental importância para a verificação da incidência do ICM sobre as operações de importações, com destaque para as realizadas mediante arrendamento mercantil, ou leasing, objeto do presente trabalho.

\section{I HiPÓTESE TRIBUTÁRIA DO ICM}

Como qualquer outro estudo no âmbito da Ciência Jurídica, o estudo da regra matriz de incidência fiscal do ICM deve se iniciar pela norma fundamental do ordenamento jurídico. Dessa maneira, o presente trabalho iniciará a exposição da regra matriz de incidência fiscal do ICM conforme os mandamentos e preceitos dispostos na constituição federal de 1988.

A constituição federal não cria ou institui tributos, mas estabelece a competência dos entes federativos (união federal, estados federados, distrito federal e municípios) para sua instituição, ou seja, estabelece quais os tipos e modalidades de tributos os entes federativos podem criar, delegando suas respectivas competências.

Com efeito, a regra matriz de incidência fiscal do ICM encontra-se previsto no artigo 155, inciso II da constituição federal, também denominada pela doutrina como matriz constitucional de incidência do tributo.

Assim dispõe o artigo 155, inciso II da Constituição Federal do Brasil de 1988 :

Art. 155. Compete aos Estados e ao Distrito Federal instituir impostos sobre:

[...]

II - operações relativas à circulação de mercadorias e serviços e sobre prestações de serviços de transporte interestadual e intermunicipal e de comunicação, ainda que as operações e as prestações se iniciem no exterior;

[...]

No âmbito da legislação infraconstitucional, a norma nacional que dispõe sobre a incidência do ICM é a Lei Complementar $n^{\circ}$. 87, de 13 de setembro de 1996, ordinariamente denominada de Lei Kandir, em referência ao parlamentar Antônio Kandir, que propôs o Projeto de Lei que redundou nesta norma.

Conforme ensina o Professor Roque Antonio Carrazza, da análise do artigo 155, incido II, da Constituição Federal de 1988, bem como da Lei Complementar nº $.87 / 96$, 
pode-se extrair cinco modalidades de tributos denominados ICM ou ICMS. Segundo o Professor, isto ocorre por conta do binômio: hipótese tributária e base de cálculo. ${ }^{32}$

Nesse passo, por existirem diferentes critérios materiais que compõem a hipótese tributária destes tributos, e, por conseguinte, diferentes bases de cálculo, havidas da relação jurídica tributária, a incidência da norma jurídica tributária pode ocorrer de cinco maneiras distintas, surgindo, a partir daí, diferentes modalidades de tributos.

Para Carrazza, as modalidades de tributos previstos da norma jurídica tributária do ICM ou ICMS são:

a) imposto sobre operações mercantis (operações relativas à circulação de mercadorias); b) o imposto sobre serviços de transporte interestadual e intermunicipal; c) o imposto sobre serviços de comunicação; d) o imposto sobre produção, importação, circulação, distribuição ou consumo de lubrificantes e combustíveis gasosos e de energia elétrica; e e) o imposto sobre a extração, circulação, distribuição ou consumo de minerais. ${ }^{33}$

No presente trabalho, que busca identificar a incidência do tributo nas operações de importação, com destaque para as realizadas mediante arrendamento mercantil, ou leasing, estudar-se-á tão somente a regra matiz de incidência fiscal deste tributo nas operações mercantis relativas à circulação de mercadorias. Por conta disto foi que se optou em denominar o tributo ora em estudo de ICM (Imposto sobre a Circulação de Mercadorias), e não de ICMS (Imposto sobre a Circulação de Mercadorias e Serviços), como este é comumente designado.

A regra matriz de incidência fiscal do Imposto sobre a Circulação de Mercadorias - ICM, foi introduzido na Contituição Federal através da Emenda Constitucional n ${ }^{\circ}$. 18, de $1^{\circ}$ de dezembro de 1965 , sendo mantido na Constituição Federal de 1967, e ainda, pela Emenda Constitucional no. 1 de 1969.

Desde o surgimento do ICM no ordenamento jurídico pátrio, a regra matriz de incidência fiscal deste tributo vincula o critério material de sua hipótese tributária à figura de operações relativas à circulação de mercadorias. Ou seja, o critério material da hipótese tributária do ICM é operação de circulação de mercadorias.

Dessa forma, para se compreender o critério material desse imposto, bem como a incidência da norma jurídico tributária, mister se faz o estudo do significado jurídico dos termos: operações, circulação e mercadoria.

Importante que seja observado o disposto no artigo 110 do Código Tributário Nacional:

Art. 110. A lei tributária não pode alterar a definição, o conteúdo e o alcance de institutos, conceitos e formas de direito privado, utilizados, expressa ou 
implicitamente, pela Constituição Federal, pelas Constituições dos Estados, ou pelas Leis Orgânicas do Distrito Federal ou dos Municípios, para definir ou limitar competências tributárias.

Os significados destes termos, portanto, devem ser extraídos dos conceitos próprios do direito privado, em especial do direito empresarial, para que uma maior clareza seja alcançada no estudo da regra matriz de incidência fiscal do ICM.

O conceito de operações, nesse aspecto, conforme entendimento majoritário da doutrina sobre a matéria, deve ser definido como sendo negócio jurídico. Segundo o Professor Marcelo Viana Salomão, “operação, em termos de direito, significa negócio jurídico, ou seja, uma manifestação de vontade que cria, modifica ou etingue direitos". 34

Citando Amaral:

Por negócio jurídico deve-se entender a declaração de vontade privada destinada a produzir efeitos que o agente pretende e o direito reconhece.

Tais efeitos são a constituição, modificação ou extinção de relações jurídicas, de modo vinculante, obrigatório para as partes intervenientes. ${ }^{35}$

No entendimento do Professor Hugo de Brito Machado, operações devem ser compreendidas como "todos aqueles atos, contratos, negócios, que são usualmente praticados na atividade empresarial". ${ }^{36}$ Para esse autor, o legislador constituinte utilizou-se da palavra operação como sendo uma expressão genérica. Nesse ponto, importante relembrar dos ensinamentos de Carvalho sobre o critério material, descritos no tópico anterior, no sentido de que este é formado por expressões genéricas designativas do comportamento dos indivíduos.

Operação, portanto, é o corpotamento do individuo que se encontra descrito no critério material da hipótese tributária, sendo este comportamento o elemento nuclear do critério material. É sobre este comportamento do indivíduo que deve incidir a norma jurídica tributária do ICM.

É assente na doutrina o entendimento de que o substantivo operação é núcleo do critério material da hipótese tributária do ICM. Nesse sentido, relevantes os ensinamentos dos Professores Geraldo Ataliba e Cléber Giardino:

O conceito nuclear da materialidade da hipótese de incidência do ICMS é o de operações. Esta é, efetivamente, uma expressão substantiva de descrição constitucional do tributo; é o núcleo em torno do qual se constrói a própria descrição do campo material de competência dos Estados. Os demais termos, constantes dessa locução constitucional, são adjetivos em torno do substantivo operações. ${ }^{37}$ 
Desse modo, o vocábulo operações é elemento central que descreve o comportamento do indivíduo previsto no critério material da hipótese tributária, o qual sobre ele deve incidir a norma jurídica tributária. Nesse aspecto, as expressões circulação e mercadorias são complementos daquele núcleo - operação -, ou seja, são estas expressões as quais qualificam os tipos de operações que são relevantes para a incidência da norma jurídica tributária do ICM, pois o tributo não incide sobre todo e qualquer tipo de operação.

Para que haja, destarte, a incidência da norma jurídica tributária do ICM sobre operações, imprecindível que estas sejam de circulação de mercadorias. Pode-se afirmar, portanto, que este é um tributo incidente tão somente sobre negócios jurídicos realizados na atividade empresarial (operações mercantis), desde que, nestes negócios jurídicos ocorra a circulação de mercadorias.

O conceito de circulação, para fins jurídicos e para que ocorra a incidência da norma jurídica tributária do ICM, deve ser compreendido como mudança de titularidade. Circulação deve ser aquela em que se ocorre a alteração do titular do bem (in casu, mercadorias), substituindo-se a pessoa que detém a disponibilidade deste bem por outra, a qual passará a ser o titular, detendo a disponibilidade sobre o mencionado bem (mercadoria).

Nas palavras de Ataliba e Giardino:

Circular significa, para o Direito, mudar de titular. Se um bem ou uma mercadoria mudam de titular, circula para efeitos jurídicos. Convenciona-se designar por titularidade de uma mercadoria a circunstância de alguém deter poderes jurídicos de disposição sobre a mesma, sendo ou não sendo seu proprietário (disponibilidade jurídica). ${ }^{38}$

Circulação, portanto, para fins de incidência da norma jurídica do ICM, deve ser considerada como sendo aquela em que ocorra a mudança de titularidade do bem (mercadoria), compreendendo a alteração da pessoa que possui a disponibilidade deste. Conforme o entendimento dos Professores acima citados, esta pessoa pode ser proprietária ou não do bem (como nos casos em que apenas existe a posse animus dominus), sendo imperativo, todavia, que esta pessoa detenha a disponibilidade deste bem.

Salomão conclui:

Destarte, apenas uma operação, isto é, um negócio jurídico, que tivesse por objeto a transferência do direito de disposição sobre determinado tipo de bem, é que configurava um fato passível de gerar a incidência do ICM. ${ }^{39}$

A simples circulação física ou econômica de determinado bem (mercadoria) não importa na incidência da norma jurídico tributária do ICM. Carraza, com a clareza que lhe é lapidar, ensina: 
É bom esclarecermos, desde logo, que tal circulação só pode ser jurídica (e, não, meramente física). A circulação jurídica pressupõe a transferência (de uma pessoa para outra) da posse ou da propriedade da mercadoria. Sem mudança da titulariedade da mercadoria, não há falar em tributação por meio de ICMS. Esta idéia, abonada pela melhor doutrina (Souto Maior Borges, Geraldo Ataliba, Paulo de Barros Carvalho, Cleber Giardino etc.), encontrou ressonância no próprio Supremo Tribunal Federal. ${ }^{40}$

Conclui-se que para a incidência da norma jurídica tributária do ICM, a circulação advinda do negócio jurídico (operação) deverá, por óbvio, ser jurídica, ou seja, deve ocorrer a mudança de titularidade da mercadoria.

Finalizando a análise do criterio material da hipótese tributária do ICM, tem-se o termo mercadoria, o qual seu estudo é fundamental para a determinação da incidência da norma jurídica tributária do ICM.

O conceito de mercadoria pode ser definido como sendo aquele bem ou coisa que é posto em mercância. É o bem produzido ou adquirido para ser inserido na atividade mercantil, ou seja, para ser colocado à venda no comércio.

Importante destacar que apenas os bens móveis podem ser considerados como mercadoria. Os bens imóveis não são alcançados pela norma jurídica tributária do ICM, mas pela norma jurídica tributária do ITBI - Imposto sobre a Transmissão de Bens Imóveis (artigo 156, inciso II da Consituição Federal de 198841), de competência dos Municípios. Nesse aspecto, para incidência da norma jurídica triutária do ICM, bens móveis devem ser entendidos como gênero, e mercadorias como espécie. Apenas os bens (ou coisas) móveis do tipo mercadorias é que são atingidas pela norma jurídica tributária do ICM, pois a tributação dos bens móveis em geral (entendida como gênero) é atingida pela norma jurídica tributária do imposto sobre doações (artigo 155, inciso I da Constituição Federal de 198842), de competência dos Estados Federados e o Distrito Federal. ${ }^{43}$

Para esclarer o conceito de mercadoria, essencial os ensinamentos de Hugo de Brito Machado:

Todas as mercadorias são coisas, mas nem todas as coisas são mercadorias. O que caracteriza um coisa como mercadoria é a destinação. Mercadorias são as coisas móveis destinadas ao comércio. São coisas adquiridas pelos empresários para revenda, no estado em que as adquiriram, ou transformadas, e ainda as produzidas para a venda. ${ }^{44}$

Por serem coisas móveis produzidas e adquiridas para a venda, com destinação à atividade mercantil, pode-se dizer, sem qualquer receio de errar, que o conceito de mercadoria é intimamente ligado à obtenção de lucro, ou seja, são coisas móveis 
destinadas a auferir ganho de capital ao empresário. Nas palavras de Aliomar Baleeiro, mercadoria é o "bem econômico que alguém, com o propósito deliberado de lucro, produz para vender ou compra para revender". 45

José Eduardo Soares de Melo, sobre o tema, ensina que:

"Mercadoria" é bem corpóreo da atividade empresarial do produtor, industrial e comerciante, tendo por objeto a sua distribuição para consumo, compreendendo-se no estoque da empresa, distinguindo-se das coisas que tenham qualificação diversa segundo a ciência contábil, como é o caso do ativo fixo. ${ }^{46}$

O que caracteriza uma mercadoria, em sua essência, diferenciando-a dos bens móveis em geral, é a sua destinação. Nesse sentido, somente os bens móveis destinados ao comércio, com o fito de obtenção de lucro pelo empresário, é que pode ser considerado mercadoria.

Para rematar evetuais dúvidas existentes sobre o tema, traz-se os ensinamentos de Carrazza, que com clareza singular, ensina:

Não é qualquer bem móvel que é mercadoria, mas tão-só aquele que se submete à mercancia. Podemos, pois, dizer que toda mercadoria é bem móvel, mas nem todo bem móvel é mercadoria. Só o bem móvel que se destina à prática de operações mercantis é que assume a qualidade de mercadoria. ${ }^{47}$

Diante do que foi exposto dos conceitos de operação, circulação e mercadoria, podese concluir que o critério material da hipótese tributária do ICM é todo o negócio jurídico praticado na atividade empresarial (operações mercantis), que resulte na alteração de titularidade (circulação), ou seja, na mudança da pessoa possuidora da disponibiliade de determinado bem móvel destinado à atividade mercantil (mercadoria), com o objetivo de auferir ganho de capital ao empresário.

A compreesão do critério material do ICM é de fundamental importância no presente estudo, pois somente através dele poder-se-á auferir a incidência deste tributo nas operações de importação, em especial as realizadas mediante arrendamento mercantil, objeto do presente trabalho.

No que concerne ao critério espacial, importante esclarecer que o ICM é um dos tipos de tributos em que o critério espacial coincide com todo o território do ente político competente para a instituição do tributo. ${ }^{48}$ Nesse aspecto, o critério espacial do ICM é todo o território do Estado Federado ou do Distrito Federal, entes federativos competentes para a instuição do ICM, conforme dispõe o art. 156, inc. II da Constituição Federal, anteriormente mencionado. 
Mais precisamente, o critério espacial do ICM será todo o território do Estado ou do Distrito Federal, competente para a instituição do tributo, no qual ocorrer o critério material da hipótese tributaria do ICM, qual seja, operação de circulação de mercadoria.

Importante mencionar que, em regra geral, o local em que se inicia a operação de circulação, ou seja, o local onde a mercadoria se encontra antes de iniciar a operação de circulação, é considerado como critério espacial da hipótese tributária do ICM. Nas palavras de Machado:

Como regra geral, o lugar em que se considera ocorrido o fato gerador do ICMS é o local do estabelecimento em que se encontra a mercadoria no momento em que se efetiva a operação relativa a sua circulação. ${ }^{49}$

O critério espacial em relação ao ICM incidente sobre operações de importação, objeto deste estudo, será distinto do anteriormente descrito, pois, tendo em vista que a mercadoria, no caso da importação, origina-se do exterior, o critério espacial será o território do Estado, ou do Distrito Federal, em que se localiza o estabelecimento destinatário da mercadoria.

Quanto ao critério temporal da hipótese tributária do ICM, a legislação optou por considerar determinado fato, determinado acontecimento, como sendo o momento em que se concretiza o critério material da hipótese tributária do ICM.

Em regra geral, a saída da mercadoria dos estabelecimentos onde se inicia a operação de circulação foi eleita pela legislação como definição do critério temporal deste tributo. ${ }^{50} \mathrm{O}$ critério temporal do ICM é, portanto, o momento em que ocorre a saída da mercadoria do estabelecimento vendedor, ou seja, quando se inicia a operação da circulação.

Confome o entendimento de Melo:

A "saída" - eleita pelo legislador como elemento do fato gerador (DL 406-

68 , art. $1^{\circ}$, I e Lei Complementar $n^{\circ} .87 / 96$ - art.12, I) - compreende o aspecto de tempo previsto na norma, uma vez que os fatos imponíveis ocorreram em um determinado momento, porque, nesse instante, nasce o direito subjetivo para a pessoa de direito público e, correlatamente, uma obrigação para o sujeito passivo. ${ }^{51}$

Com a saída da mercadoria do estabelecimento onde se inicia a operação de circulação, a hipótese tributária da regra matriz de incidência fiscal do ICM concretiza-se, por completo, no univeso das realidades materiais, dando nascimento, diga-se, através do lançamento tributário (linguagem competente), ao fato jurídico tributário, o qual estará apto a gerar efeitos no campo do direito. 
O efeitos propagados pelo fato jurídico tributário, conforme anteriormente delineado, é o surgimento de uma relação jurídica triutária. Esta relação jurídica tributária será abordada no tópico subsequente, finalizando o estudo da regra matriz de incidência fiscal do ICM, para que, posteriormente, possa-se compreender a incidência deste tributo sobre as operações de importação, em especial para aquelas realizadas mediante arrendamento mercantil, ou leasing, que é o objeto principal do presente trabalho.

\section{I.2 Relação JURídicA TRIBUTÁRIA DO ICM}

A partir da incidência da norma jurídica tributária do ICM, que ocorre após a concretização da hipótese tributária no mundo das realidades materiais, surge, então, o fato jurídico tributário, o qual irradiará efeitos da norma no mundo jurídico. Esses efeitos, conforme anteriormente mencionado, são o nascimento de uma relação jurídica tributária, a qual é identificada através de critérios previstos na própria norma jurídica.

Trata-se dos critérios pessoal e quantitativo, os quais devem estar presentes para que sejam propagados os efeitos da norma jurídica tributária, pois somente através destes critérios pode se precisar quais as pessoas envolvidas na relação jurídica tributária surgida com a concretização da hipótese tributária, bem como seu objeto.

O critério pessoal, como se sabe, é composto pelos seguintes elementos: sujeito ativo e sujeito passivo.

No caso do ICM, o critério pessoal tem como sujeito ativo, ocupando a posição de credor da relação jurídica tributária, o Estado-membro ou o Distrito Federal competente para a instituição do tributo. Para Salomão, "geralmente preenchem este pólo da relação tributária as pessoas políticas de direito constitucional interno, ou seja, quem tem competência tributária”. ${ }^{52}$

Em regra, pode-se dizer que o sujeito ativo do ICM será todo aquele estadomembro, ou o distrito federal, titular da competência tributária, em que está localizado o estabelecimento onde se encontra alocada a mercadoria, quando se concretiza o critério material da hipótese tributária, ou seja, quando se efetiva a circulação desta mercadoria.

Para o professor Hugo de Brito Machado, o ICM será devido "ao Estado em cujo território está sediado o estabelecimento onde se verifica a saída da mercadoria”. 53

Quanto ao sujeito passivo da relação jurídica tributária do ICM, o qual ocupa a posição de devedor na relação jurídica tributária, deve ser aquele que realizar o critério material da hipótese tributaria, ou seja, aquele que efetivar uma operação de circulação de mercadoria.

Por ser a operação de circulação de mercadorias um negócio jurídico perpetrado na atividade empresarial (operações mercantis), pode-se afirmar, de maneira genérica, que o sujeito passivo será todo aquele que exerce atividade empresarial (empresários). Mais precisamente, conforme o entendimento consolidado pela doutrina, apenas poderá ser 
sujeito passivo, via de regra, o produtor, o industrial ou o comerciante, ou seja, as pessoas que desenvolvem atividade empresarial. 54

Pessoa diversa, que não esteja inserida na atividade empresarial, não poderá ser sujeito passivo do tributo, posto que realizem uma venda de um bem móvel qualquer. A atividade realizada por pessoa diversa do empresário não será enquadrada no critério material da hipótese tributária deste tributo, pois estas pessoas não realizam, de forma habitual, atividade empresarial.

Relevantes os ensinamentos de Carrazza:

E quem pode promover a realização de tais operações? Entendemos que só o produtor, o industrial ou o comerciante. O particular (dona de casa, operário, aposentado etc.) que vende um objeto seu não realiza uma operação relativa à circulação de mercadorias; apenas vende um bem móvel qualquer. O mesmo podemos dizer do profissional liberal (médico, dentista, advogado), do professor, do funcionário público, enfim, de todos os que não revestirem uma destas três condições: comerciante, industrial ou produtor. ${ }^{55}$

Pode-se afirmar, de forma geral, que apenas o produtor, o industrial ou o comerciante podem ser sujeito passivo da relação jurídica tributária do ICM, pois atuam na atividade empresarial, de maneira habitual, a qual é o âmbito central da incidência deste tributo.

O segundo critério que identifica a relação jurídica tributária é o critério quantitativo, aquele que caracteriza o objeto da relação jurídica tributária, ou seja, a prestação pecuniária (o valor do tributo). Este critério é composto pelos elementos: base de calculo e alíquota.

A base de cálculo, por atuar como grandeza que se destina a dimensionar o critério material da hipótese tributária, conforme disposto anteriormente, no que concerne ao ICM, esta deve necessariamente ser uma medida da operação mercantil realizada ${ }^{56}$. Ou seja, a base de cálculo da relação jurídica do ICM deverá ser o valor da operação de circulação de mercadoria, a qual, em regra geral, é o valor da própria mercadoria.

Machado é contundente ao dizer que: "a base de cálculo do ICMS não pode ser algo diverso do valor da operação em se tratando de circulação de mercadorias". 57

Nas palavras de Melo, “a base deve representar a quantificação compreendida na 'operação mercantil'”. 58

A base de cálculo da relação jurídica do ICM, conforme pode se observar, será, necessariamente, o valor da operação de circulação de mercadoria realizada.

Por fim, a alíquota, que é o segundo elemento que compõe o critério quantitativo da relação jurídica tributária. Nesse aspecto, importante relembrar as considerações anteriormente efetuadas quanto à alíquota, principalmente por ela ser um fator 
aplicável sobre a base de cálculo, a fim de se auferir o montante de tributo que o sujeito passivo deverá pagar.

No caso do ICM, a alíquota é geralmente um elemento aritmético, o qual, na grande maioria das vezes, se resume em uma porcentagem aplicada sobre a base de cálculo deste tributo.

As alíquotas, no que diz respeito ao ICM, devem ser fixadas por meio de lei ordinária dos entes políticos com competência tributária (Estados Federados e Distrito Federal), devendo ser observado o disposto nas alíneas a e $b$, do inciso $\mathrm{V}, \S 2^{\circ}$, do artigo 155 da Constituição Federal, ${ }^{59}$ as quais estabelecem a faculdade do Senado Federal em aplicar alíquotas mínimas e máximas nas operações internas, mediante a publicação de resoluções. 60

Importante que se diga que a alíquota do ICM poderá variar conforme o Estado em que se efetivou a operação de circulação de mercadoria, haja vista a autonomia dos entes federativos. No mesmo sentido, também poderá ocorrer variações das alíquotas conforme os diferentes tipos de mercadorias em que foram efetivadas operações de circulação, em atenção ao princípio constitucional da seletividade a qual a norma jurídica deste tributo deve observar (art. 155, $\S 2^{\circ}$, inciso III, da Constituição Federal ${ }^{61}$ ).

Feitas estas considerações quanto à relação jurídica tributária do ICM, bem como diante de tudo o que foi exposto no tópico anterior sobre a hipótese tributária deste tributo, finaliza-se o estudo da regra matriz de incidência fiscal do ICM, a qual será de imperativa importância para análise da incidência deste tributo nas operações de importação, especialmente as realizadas mediante arrendamento mercantil (leasing).

Apenas com a finalidade de resumir, em uma breve síntese do que foi exposto, pode-se dizer, de maneira genérica, que a regra matriz de incidência fiscal do ICM deve ser composta por hipótese tributária, cuja concretização enseja uma relação jurídica tributária.

A hipótese tributária do ICM deve ser identificada através dos critérios: (i) material: realizar operação de circulação de mercadoria; (ii) espacial: território do estado-membro ou distrito federal; e (iii) temporal: momento da saída da mercadoria do estabelecimento vendedor.

No que concerne à relação jurídica tributária surgida, esta deve ser identificada pelos critérios: (i) pessoal: tendo como sujeito ativo o Estado-membro e o Distrito Federal, e sujeito passivo os produtores, industriais e comerciantes e (ii) quantitativo: formada pela base de cálculo, que é o valor da operação de circulação de mercadoria, e alíquota, que, em regra, uma percentagem prevista nas legislações competentes.

Entendida a regra matriz de incidência fiscal do ICM, passa-se, nos próximos tópicos, à análise da incidência deste tributo nas operações de importações, principalmente as realizadas mediante arrendamento mercantil (leasing). 


\section{DO ICM NA IMPORTAÇÃO}

A incidência do ICM sobre a importação iniciou-se através de uma grande pressão política dos Estado Federados frente ao Governo Federal, exercida no começo da década de 1980, com o intuíto de aumentar suas arrecadações.

Nesse período, os estados federados, com fundamento em legislação própria, infraconstitucional, em evidente arrepio à Constituição Federal do Brasil vigente à época, efetuavam a cobrança deste tributo quando ocorria a entreda de mercadorias, e de qualquer outro tipo de bem, no estabelecimento importador.

Esta cobrança, efetuada sem qualquer respaldo constitucional, foi afastada pelo poder judiciário, por meio do Supremo Tribunal Federal. Todavia, é de conhecimento público que os estados federados e o distrito federal, objetivando alargar suas arrecadações, fizeram aprovar a Emenda Constitucional n. 23 de 1983. A emenda trouxe à constituição federal, pela primeira vez, a previsão da incidência do ICM sobre as entrada de mercadorias e bens importados do exterior (importação).

A mencionada emenda consitucional acresceu o $§ 11$ ao artigo 23, da Constituição anterior, de 1967, que dispunha sobre o ICM, trazendo a incidência deste tributo sobre a importação:

\section{Art. $23[\ldots]$}

[...]

$\S 11$. O imposto a que se refere o item II incidirá, também, sobre a entrada, em estabelecimento comercial, industrial, ou produtor, de mercadoria importada do exterior por seu titular, inclusive quando se tratar de bens destinados a consumo ou ativo fixo do estabelecimento.

A pretensão dos estados federados e do distrito federal em efetuar a cobrança do ICM sobre a importação, antes sem qualquer amparo constitucional, a partir daí, efetiva-se com respaldo na norma fundamental do ordenamento jurídico brasileiro.

Mais recentemente, a Constituição Federal do Brasil de 1988 manteve integralmente a previsão disposta na Constituição anterior (1967), com algumas alterações posteriores, advindas da Emenda Constitucional n. 33 de 2001, cuja constitucionalidade é muito discutida entre a doutrina. Contudo, a constitucionalidade ou não desta Emenda não será abordada no presente estudo, por não ser objeto principal deste trabalho.

Assim, dispõe a atual redação da norma constitucional de incidência do ICM, a qual dispõe sobre a incidência do tributo nas operações de importação:

Art. 155. Compete aos Estados e ao Distrito Federal instituir impostos sobre: [...]

II - operações relativas à circulação de mercadorias e sobre prestações de serviços de transporte interestadual e intermunicipal e de comunicação, ainda 
que as operações e as prestações se iniciem no exterior;

[...]

$\S 2^{\circ} \mathrm{O}$ imposto previsto no inciso II atenderá ao seguinte:

[...]

IX - incidirá também:

a) sobre a entrada de bem ou mercadoria importados do exterior por pessoa física ou jurídica, ainda que não seja contribuinte habitual do imposto, qualquer que seja a sua finalidade, assim como sobre o serviço prestado no exterior, cabendo o imposto ao Estado onde estiver situado o domicílio ou o estabelecimento do destinatário da mercadoria, bem ou serviço;

$[\ldots]$

A partir da norma constitucional que prevê a incidência do ICM na importação, pode-se iniciar o estudo da regra matriz de incidência fiscal deste tributo, especificamente voltando-se à análise para as operações de importação, a fim de que, posteriormente, possa-se verificar sua incidência nas importações mediante arrendamento mercantil, objeto nuclear do presente trabalho.

Importante esclarecer que, assim como foi efetuado no tópico anterior, a regra matriz de incidência fiscal do ICM nas importações será abordado dando-se maior ênfase ao estudo do critério material da hipótese tributária deste tributo.

Isto ocorre, porque o critério material será determinante para análise da incidência do ICM nas importações realizadas mediante arrendamento mercantil. Os outros critérios existentes também serão abordados, contudo, apenas com a finalidade de fixação e entendimento geral da incidência do tributo na importação.

Por meio da norma constitucional acima mencionada, pode-se visualizar que a hipótese tributária da regra matriz de incidência fiscal do ICM, antes possuindo como critério material somente a figura de operações relativas à circulação de mercadorias, agora é mais abrangente, englobando também a entrada de bens ou mercadorias importados do exterior, ou seja, a importação.

Como elemento central do critério material da hipótese tributária do ICM, incidente sobre a entrada de bens e mercadorias do exterior, tem-se a figura jurídica identificada pelo vocábulo importação.

Sobre o tema, válidos os ensinamentos de Carrazza:

Assim, o elemento nuclear, a essência, do critério material, desvinculado de qualquer outro condicionante (temporal e espacial), na hipótese de incidência do ICMS nas importações de mercadorias ou bens, indentifica-se com o verbo importar. ${ }^{62}$

Buscando o conceito de importação no Direito Empresarial, assim como se fez nos 
vocábulos operação, circulação e mercadoria, tem-se que importar "é a colocação de produtos ou mercadorias estrangeiras no mercado brasileiro. São as mercadorias que entram para o consumo". 63

O ICM sobre a importação, inicialmente, apenas incidia sobre a entrada de mercadorias do exterior. Especificamente com as alterações perpetradas pela Emenda Consitucional n. 33/2001, o tributo passou a incidir sobre todo e qualquer bem importado. Ou seja, houve um alargamento do critério material do ICM, nos casos de importação, pois, agora, o tributo incide sobre todo e qualquer tipo de bem importado, e não apenas mercadorias.

A partir da Emenda Constitucional n. 33/2001, o ICM incidente nas importações não estará restrito aos negócios jurídico praticados na atividade empresarial, que objetivam ganho de capital (lucro), como ocorre na incidência do tributo nas operações de circulação de mercadorias, pois, conforme o disposto na norma constitucional, o tributo, nas operações de importação, incide independentemente da finalidade da operação.

Tendo como base este raciocínio quanto ao critério material, pode-se induzir que o ICM incidente nas importações teria o condão de incidir sobre toda e qualquer operação de importação, haja vista que este tributo incide sobre a entrada de qualquer bem ou mercadoria advinda do exterior. Conduto, exatamente neste ponto, a doutrina diverge para entendimentos distintos, os quais são diretamente relacionados a este critério material e à incidência do tributo nas importações mediante arrendamento mercantil, que se verá mais à frente.

O primeiro entendimento, o qual é acompanhado pelos Professores Paulo de Barros Carvalho, Roque Antônio Carrazza, Gabriel Lacerda Troianelli, entre outros, sustenta que o critério material na importação está vinculado à necessidade de transferência de titularidade do bem ou mercadoria importada, sendo somente estes os casos em que ocorreria a incidêcia do tributo.

O segundo entendimento decorre dos estudos do professor Marcelo Viana Salomão, o qual sustenta que o ICM na importação, em verdade, seria um novo tributo, possuindo critério material e base de cálculo completamente desvinculados do critério material e da base de cálculo do tradicional ICM (incidente sobre operações de circulação de mercadorias). A este novo tributo o autor prefere denominar de "Imposto de Importação Estadual".

Um estudo mais aprofundado destas duas perspectivas doutrinárias será efetuado mais adiante (subtópicos 3.1 e 3.2), para que se possa analisar com maior cautela o critério material do ICM nas operações de importação. Por hora, passa-se a identificação dos demais critérios da regra matriz de incidência fiscal do ICM nas operações de importação.

O critério espacial da hipótese tributária deste tributo é definido como sendo o território do Estado-membro ou do Distrito Federal onde se situa o domicílio ou estabelecimento destinatário do bem ou mercadoria importada. Ou seja, é o local do 
domicílio ou estabelecimento onde ocorre a entrada do bem ou mercadoria. Nesse sentido, cita-se a doutrina de Machado:

Quando a mercadoria é importada do exterior, o local da operação é aquele em que tem sede o estabelecimento no qual ocorre a entrada física da mercadoria. Mesmo que esse estabelecimento seja diverso daquele que realizou a importação. ${ }^{64}$

Relevante os ensinamentos de Salomão sobre o tema:

Quanto ao critério espacial, hoje ele é precisamente definido em nosso ordenamento jurídico como sendo o limite geográfico dos Estados e, se for o caso, do Distrito Federal, onde estiver situado o estabelecimento em que ocorrer a entrada física a mercadoria ou bem. ${ }^{65}$

No que concerne ao critério temporal da hipótese tributária do ICM na importação, a Lei Complementar $n^{\circ} .87 / 96$, em seu artigo 12, inciso IX, ${ }^{66}$ estabelece que este será o momento em que ocorrer o desembaraço aduaneiro do bem ou mercadoria importada.

Nas palavras de Machado, "em se tratando de mercadorias regularmente importadas do exterior, o fato gerador do imposto considera-se ocorrido no momento do respectivo desembaraço aduaneiro". 67

Doutrinadores como Marcelo Viana Salomão e José Eduardo Soares de Melo sustentam que o critério temporal deverá ser o momento em que se configura o critério material da hipótese tributária, ou seja, o instânte em que ocorre a entrada do bem ou mercadoria importada no domicílio ou estabelecimento do importador.

Segundo este entendimento, o dispositivo da mencionada lei complementar contraria a consituição federal, pois reporta ocorrido o fato jurídico tributário sem que se tenha efetivado o critério material da hipótese tributária, ou seja, sem que se tenha ocorrida a entrada, do bem ou mercadoria importada, no domicílio ou estabelecimento do importador.

Para Melo:

O momento fixado para o nascimento da obrigação tributária -

“desembaraço aduaneiro" - é anterior ao instante em que a CF reputa acontecido o tributo - "entrada” (art. 155, § 2 , IX, a) no estabelecimento do contribuinte $[\ldots] .{ }^{68}$

No que diz respeito à relação jurídica tributária surgida pela concretização da norma jurídica tributária (do ICM na importação) no universo das realidades 
materias, da mesma forma, tem-se como elementos do critério pessoal o sujeito ativo e sujeito passivo.

O sujeito ativo do ICM na importação será o Estado-membro ou o Distrito Federal, competente para a intituição e cobrança do tributo, no qual se localizar o domicílio ou estabelecimento destinatário do bem ou mercadoria importada. Nas palavras de Carrazza, "o tributo é devido, nesta caso, ao Estado onde estiver situado o estabelecimento destinatário da mercadoria”. 69

Sobre o tema, relevantes são os esclarecimentos de Machado:

Quando a mercadoria é importada por estabelecimento localizado em um Estado, mas é destinada a estabelecimento localizado em outro, é do Estado em cujo território está este último a competência para cobrar o imposto. ${ }^{70}$

Corroborando este entendimento, tem-se a doutrina de Melo, que entende:

[...] a titularidade do imposto (sujeito ativo da relação jurídico-fiscal) não cabe singelamente ao Estado onde ocorreu o mero ato físico o desembaraço, mas ao Estado onde se localiza o sujeito passivo do tributo, isto é, aquele que juridicamente promoveu o ingresso das mercadorias estrangeiras no País, e para onde se destinam. ${ }^{71}$

Quanto ao sujeito passivo do ICM na importação, importante que se diga que este foi absurdamente alargado pela já mencionada Emenda Constitucional $\mathrm{n}^{\circ}$. 33/2001. Esta emenda estabeleceu como sujeito passivo deste tributo: “(...) pessoa física ou jurídica, ainda que não seja contribuinte habitual do imposto (...)”. Nesse aspecto, pode-se chegar a conclusão que toda e qualquer pessoa, física ou juridica, estará sujeita ao tributo, independentemente de exercer atividade empresarial, ou ser contribuinte do tributo, caso realize importação de bem ou mercadoria.

No entendimento de Melo:

Assim, considerando que o novo texto constitucional ampliou o rol de contribuintes, deve ficar prejudicada a postura assumida pelo STF ("não incidência do ICMS nas importações realizadas por pessoas físicas e sociedades civis”), relativamente aos fatos geradores realizados após a edição da legislação ordinária competente, observado o princípio da anterioridade. ${ }^{72}$

Não obstante este entendimento, a título de conhecimento, relevante trazer o posicionamento do Professor Marcelo Viana Salomão, exarado no II Congresso de Direito Tributário do Instituto de Direito Tributário de Londrina (IDTL), em 2007, 
quando o professor lecionou sobre o tema "O ICMS na Importação após a Emenda 33 e a Jurisprudência do STJ e STF”.

Para o autor, o dispositivo constitucional, quando menciona "pessoa física ou jurídica, ainda que não seja contribuinte habitual do imposto” não deve ser entendido como toda e qualquer pessoa física ou jurídica, mas somente aquela pessoa que seja contribuinte do ICM, ainda que de forma não habitual. Isto, porque, apenas pode ser "contribuinte não habitual", quem é contribuinte do tributo.

Em outras palavras, o entendimento do Professor é no sentido de que o sujeito passivo do ICM incidente sobre a importação deve ser, necessariamente, contribuinte do ICM, ainda que não habitual, ou seja, deve ser aquela pessoa cadastrata no ente político como contribuinte, por realizar uma das outras formas de incidência do tributo (operações mercantis, serviços de transporte interestadual e intermunicipal, serviços de comunicação e etc), ainda que esta pessoa seja um contribuinte não habitual.

Portanto, para Salomão, quem não for contribuinte do tributo, não poderá ser considerado sujeito passivo do ICM incidente na importação de bens ou mercadorias do exterior.

Este posicionamento é corroborado por Carrazza, que assim dispõe sobre o tema:

Ou seja, esta hipótese só alcança as importações realizadas por um contribuinte do ICMS, o que é figura semelhante à de incidência do imposto nas operações interestaduais a consumidor final, em que o Estado de destino só tem competência impositiva se o destinatário for contribuinte de ICMS. 73

No que concerne aos elementos do critério quantitativo da relação jurídica tributária do ICM na importação, tem-se que a base de cálculo deste tributo, de maneira geral, será o valor da operação de importação de mercadoria ou bens. Ou seja, a base de cálculo deve ser o valor pelo qual ocorreu a entrada dos bens ou mercadorias no país.

Cita-se Machado:

Em se tratando de importação de mercadorias, ou bens (...), a base de cálculo do imposto é o custo da importação, como tal entendo o valor da mercadoria ou bem, constante dos documentos de importação, convertido em moeda nacional pela mesma taxa de câmbio utilizada para o cálculo do imposto de importação, $[\ldots] .{ }^{74}$

Quanto ao critério quantitativo do ICM incidente na importação, tem-se o seu segundo elemento, qual seja, a alíquota. Sobre a alíquota do ICM na importação, o que importa mencionar é que, assim como no tradicional ICM (incidente sobre operações 
de circulação de mercadoria), ela será uma porcentagem estabelecida pela legislação do estado-membro, ou do distrito federal, conforme o caso, competente para a instituição e cobrança do tributo.

Salomão, referindo-se à alíquota do ICM na importação, ensina que ela sempre “deverá ser uma porcentagem definida pela legislação competente, ou a denominada “alíquota específica” prevista no art. 20, I, do Código Tributário Nacional”. ${ }^{75}$

Sendo esta a regra matriz de incidência fiscal do ICM nas operações de importação, pode-se ter uma noção geral de como se dá a incidência deste tributo nas operações de entrada de bens ou mercadorias da exterior.

Nos tópicos seguinte, efetuar-se-á uma análise mais abrangente do critério material da hipótese tributária deste tributo, em relação às operações de importação, conforme anteriormente mencionado, analisando-se os diferentes posicionamentos da doutrina sobre este tema.

\section{I ICM SOBRE OPERAÇÕES DE IMPORTAÇÃO}

Sobre o tema ora em estudo, doutrinadores como Paulo de Barros Carvalho, Roque Antônio Carrazza, Gabriel Lacerda Troianelli, entre outros, sustentam que o critério material do ICM incidente sobre a importação de bens ou mercadorias do exterior, ao contrário do que aparenta, não poderá incidir sobre todo e qualquer bem ou mercadoria importada. Para estes estudiosos, o ICM apenas incide naquelas operações de importação em que ocorre a transferência de titularidade do bem ou mercadoria importada.

Nos fundamentos deste posicionamento doutrinário, o ICM não incide sobre a simples importação de produtos (bens ou mercadorias), mas sobre operações de importação. Nesse aspecto, o termo operação, conforme exposto no subtópico 1.1, deve ser entendido como ato ou negócio juríco.

Para que sobrevenha a incidência do tributo na importação, assim como se dá no ICM incidente sobre operações de circulação de mercadorias, não basta que ocorra qualquer negócio jurídico, mas tão somente aqueles em que haja "circulação”, ou seja, a transferência de titulariadade do produto (bem ou mercadoria) importado.

No entendimento de Carraza, isto se dá, pois, a matriz constitucional do tributo incidente sobre operações de circulação de mercadorias, ressalva a incidência deste imposto "ainda que as operações e as prestações se iniciem no exterior", o que se dá através da importação (art. 155, inciso II, parte final).

Assim, dispõe Carrazza:

Estamos, em suma, diante de um verdadeiro imposto sobre operações mercantis, embora, como estipula o art. 155, II, "in fine", da CF, elas "se iniciem no exterior". Por isso, deve obedecer aos principios próprios do ICMS, como o da não-cumulatividade. ${ }^{76}$ 
Para este entendimento doutrinário, não seria a simples entrada do bem ou mercadoria do exterior que ensejaria a incidência do ICM nestas operações, mas somente àquelas em que ocorra a transferência de titularidade do produto importado.

Nas palavras de Carraza, "na realidade, o que estamos querendo deixar patenteado é que o fato importação não despe o ICMS ora em estudo de seu caráter mercantil. A importação, no caso, há de ser relativa à circulação de mercadorias”. 77

Cristiano Maciel Carneiro Leão, em sua tese de Mestrado em Direito pela Pontifícia Universidade Católica de São Paulo (PUC/SP), em 2007, discorrendo sobre o tema “A emenda constitucional 33/01 e o 'novo' ICMS - importação: manutenção da 'transferência de titularidade' como núcleo constitucional da materialidade do ICMS - importação”, cita considerações relevantes sobre o tema, efetuadas por Carvalho (apud LEÃO, 2007, p. 135):

Nota-se que em nenhum momento o constituinte pretendeu ampliar a hipótese de incidência do ICMS para que este passasse a abranger a mera entrada física do bem, sem a efetiva transferência da sua titularidade (operação de circulação de mercadoria). ${ }^{78}$

Neste mesmo trabalho, Leão, continuando sua explanação sobre o assunto, expõe que: "o novo ICMS - importação somente pode atingir operações de importações calcadas em negócios jurídicos relativos à circulação jurídica dos objetos importados". ${ }^{79}$ E para corroborar seu entendimento, cita considerações de Gabriel Lacerda Troianelli (2002, p. 81, apud LEÃO, 2007, p. 136), as quais merecem ser importadas ao presente estudo:

Ora, se o art. 155, § 2 , IX, “a”, continua se referindo, tal qual sua redação original, à entrada de bem ou mercadoria, não há porque se atribuir a esse termo acepção diversa daquela sempre admitida pela jurisprudência para passar a admitir a incidência do ICMS na mera circulação física de um bem. ${ }^{80}$

Como se pode perceber, este posicionamento considera que, para o ICM incidir sobre operações de importação, imperativo que ocorra a transferência de titularidade do bem ou mercadoria (circulação), quando da sua entrada do exterior no país.

As operações de importação devem respeitar a matriz constitucional do ICM, a qual prescreve a incidência o imposto somente sobre operações de circulação, ou seja, negócio jurídicos em que ocorra a transferência de titularidade do bem ou mercadoria.

Para esta corrente doutrinária, a incidência do ICM nas importações está vinculado à necessidade de transferência de titularidade do bem ou mercadoria importada, sendo somente estes os casos em que ocorreria a incidêcia do tributo. 


\subsection{IMPOSTO DE IMPORTAÇÃo ESTADUAL}

O segundo entendimento decorre dos estudos do professor Marcelo Viana Salomão, consagrados em sua obra "ICMS na Importação", originário de dissertação de mestrado em Direito pela Pontifícia Universidade Católica de São Paulo (PUC/SP), apresentada em 1997. Dessa maneira, as explanações efetuadas neste tópico são todas consubstanciadas na obra deste autor (pp. 56-85), que defende a incidência do tributo sobre toda e qualquer tipo de entrada de mercadoria importada do exterior, independente de haver ou não a transferência de titularidade do produto importado. ${ }^{81}$

Para Salomão, o ICM na importação, em verdade, seria um novo tipo de incidência deste tributo, possuindo o binômio hipótese tributária/base de cálculo inteiramente desvinculados do binômio do ICM incidente sobre operações de circulação de mercadorias. A este novo tipo de incidência do ICM o autor prefere denominar de "Imposto de Importação Estadual".

Este novo binômio (hipótese tributária/base de cálculo) tem como critério material da hipótese tributária deste tributo a figura de: importar mercadorias ou bens do exterior; e como base de cálculo da relação jurídica tributária: o valor da mercadoria ou bem importado.

Para o doutrinador, por averiguar-se um novo binômio hipótese tributária/ base de cálculo, pode-se concluir que não se está mais diante de um imposto sobre operações relativas à circulação de mercadorias, mas sim de um verdadeiro imposto de importação.

Consubstanciando suas afirmações, Salomão fundamenta que o próprio constituinte deixou evidente que sua intenção era criar uma nova forma de incidência para o ICM, quando inseriu o termo "incidirá também” na norma constitucional do tributo. Dessa maneira, trata-se de uma incidência realmente diferente da descrita no inciso II, do artigo 155, da Constituição Federal, pois, caso contrário, esta menção seria absolutamente desnecesária, pois já estaria compreendida pelas regras deste tributo.

Em sua obra, Salomão apontada uma diferença entre os tipos de incidência do ICM e deste "Imposto de Importação Estadual”, a qual, segundo seu posicionamento, é de fundamental importância, pois se relaciona diretamente com a identificação do critério material do tributo, qual seja: o ICM incide tão somente sobre mercadorias, enquanto o "Imposto de Importação Estadual" (ICM na importação) incide sobre mercadorias e bens. Diante destes aspectos, que são fundamentais para a identificação do critério material, pode se identificar que tratam-se de tributos completamente distintos.

A expressão "ainda que as operações e as prestações se iniciem no exterior" é intensamente criticada pelo Professor, o qual destaca esta como uma falha redacional do legislador constituinte, devendo ser corrigida pela doutrina, pois o legislador considerou possível a "quase concretização" do fato jurídico tributável, 
ou seja, a tributação de um evento antes da sua concretização, haja vista a impossibilidade de se tributar uma operação que ocorre no exterior, fora do campo de competência dos Estados.

Segundo Salomão, em decorrência do princípio da territorialidade, pouco importa onde teve início a operação mercantil tributada pelo ICM, pois os Estados apenas poderão tributar fatos ocorridos dentro do seus território. Dessa maneira, este termo é mais um erro redacional do constituinte, o qual não gera qualquer efeito jurídico em relação ao ICM incidente sobre operações de circulação de mercadorias, tão pouco, quanto ao incidente sobre a importação.

Defendendo seu posicionamento, Salomão sustenta que não fere o princípio da federação, o fato do ICM incidir sobre a simples entrada de bem ou mercadoria do exterior (Imposto de Importação Estadual), pois ainda assim a União continua tendo autonomia em relação aos Estados, permanecendo responsável pelas relações intenacionais e às referentes ao comércio exterior. Ressalta, ainda, que quem outorgou competência para os Estados Federados e o Distrito Federal para a instituição e um imposto de importação foi o mesmo constituinte que outorgou competência à União para tributar este mesmo evento (importações). Ou seja, ambas as outorgas são decorrentes da mesmo fonte: o Poder Constituinte Originário.

Para este posicionamento, portanto, o ICM na importação é um tributo completamente desvinculado do ICM incidente em operações de circulação de mercadorias, não necessitando, para sua exigência, que ocorra a transferência de titularidade dos produtos (bens ou mercadorias) importados. A incidência deste tributo ocorreria pela simples entrada dos bens ou mercadorias do exterior.

\section{O ICM NA IMPORTAÇÃO MEDIANTE ARRENDAMENTO MERCANTIL}

Muito se discute atualmente quanto à incidência do ICM nas operações de importação realizadas mediante arrendamento mercantil, o qual é comumente denominado, na prática do comércio exterior, de leasing internacional. Tal discussão se dá, justamente, por não restar pacífico, na doutrina e jurisprudência, se o ICM incide pela simples entrada do bem ou mercadoria importada do exterior, ou se esta entrada deve, necessáriamente, ocorrer a transferência de titularidade dos produtos importados, conforme se verificou no tópico anterior.

Antes de se analisar esta incidência, contudo, importante entender, de maneira geral, como funciona o arrendamento mercantil (comumente denominado de leasing), em especial, compreendendo o conceito deste instituto para o Direito Empresarial, e sua utilização nas operações de importação.

Existe diferentes modalidades e tipos de arrendamento mercantil ou leasing utilizados na prática empresarial, contudo, no presente estudo, esta operação será abordada de maneira genérica, apenas com a finalidade de entendimento e compreensão de seu 
conceito, para que se possa analisar a incidência do ICM na importação efetuada mediante este tipo de operação comercial.

A palavra leasing é originária do verbo inglês to lease que significa "arrendar", "tomar em arrendamento", tendo como palavra correlata a expressão leasehold, que se traduz como "posse por arrendamento". ${ }^{82}$ Ou seja, o leasing nada mais é do que a designação na lingua inglesa (a mais utilizada no comércio exterior) para o instituto que no ordenamento brasileiro é conhecido como arrendamento mercantil.

Sobre o arrendamento mercantil ou o denominado leasing, traz-se os ensinamentos do professor Roberto de Oliveira Murta:

O contrato de leasing tem por objetivo o arrendamento de máquinas ou equipamentos, por tempo determinado, mediante renda estabelecida de modo fixo entre arrendador (leaser) e arrendatário (leased ou leaseholder) ou como porcentagem sobre os lucros auferidos por este. [...] Consiste numa operação realizada entre pessoas jurídicas - arrendador e arrendatário - cujo objeto seja a locação de bens adquiridos a terceiros, pelo arrendador, com a finalidade precípua de utilização dos mesmos pelo arrendatário, de acordo com as suas especificações. ${ }^{83}$

De maneira mais prática, cita-se o Professor Arnoldo Wald, o qual conceitua este instituto como:

[...] um contrato pelo qual uma empresa, desejando utilizar determinado equipamento, ou um certo imóvel, consegue que uma instituição financeira adquira o referido bem, alugando-o ao interessado por prazo certo, admitindo-se que, terminado o prazo locativo, o locatário possa optar entre a devolução do bem, a renovação da locação ou a compra pelo preço residual fixado no momento inicial do contrato. ${ }^{84}$

O arrendamento mercantil ou leasing, portanto, assemelha-se muito a um contrato de locação, haja vista que inexiste, a princípio, a venda e compra do bem arrendado. O arrendador (pessoa jurídica especializada neste tipo de operação) realiza a compra de determinado bem, com a finalidade precípua de disponibilizá-lo, ao arrendatário, mediante uma remuneração mensal e por um determinado período de tempo.

Segundo a definição de Maria Helena Diniz, assim tem-se o conceito de arrendamento mercantil ou leasing.

É um contrato pelo qual uma pessoa jurídica ou física, pretendendo utilizar determinado equipamento, comercial ou industrial, ou certo imóvel, consegue que uma instituição financeira o adquira, arrendando-o 
ao interessado por tempo determinado, possibilitando-se ao arrendatário, findo tal prazo, optar entre a devolução do bem arrendado mediante um preço residual, previamente fixado no contrato, isto é, o que fica após a dedução das prestações até então pagas. Trata-se do financial leasing, norte americano e do creditbail dos franceses. ${ }^{85}$

Relevantes, ainda, os ensinamentos do professor Luiz Mélega:

Seguindo na esteira dos notáveis juristas atrás citados (Profs. Konder Comparato, Oviedo e B. Garcia Hilário), poderíamos definir o leasing, na sua forma por assim dizer ortodoxa, como um contrato bilateral comutativo celebrado entre pessoas (preferencialmente jurídicas), tendo por objeto o arrendamento de bens adquiridos a terceiros por uma delas, denominada arrendadora (empresa leasing), para fins de uso próprio da outra, denominada arrendatária, aquisição esta feita segundo as especificações desta última, a qual, ao fim do prazo contratual, tem as seguintes opções: a) ou devolver o bem à sociedade arrendadora, dele proprietária; b) ou adquiri-lo pelo seu valor residual; c) ou continuar na sua posse por tempo indeterminado, pagando o respectivo aluguel. 86

O leasing ou arrendamento mercantil, como se vê, é um contrato típico, com previsão na Lei $n^{\circ}$. 6.099/74, no qual o arrendador (proprietário) transfere, temporariamente, apenas a posse imediata de um determinado bem ao arrendatário, mediante remuneração periódica, sendo que, ao final, o bem arrendado poderá: (i) retornar ao arrendador, proprietário do bem, (ii) ser adquirido (comprado) pelo arrendatário; ou ainda, (iii) continuar na posse do arrendatário, renovando-se o contrato de arrendamento mercantil ou leasing.

Pode-se observar, portanto, que no arrendamento mercantil inocorre a transferência de titularidade do bem arrendado, uma vez que, o arrendador transfere, temporariamente, tão somente a posse imediata de um bem ao arrendatário, sendo que, ao final do contrato, o bem poderá retornar para o arrendador.

A titularidade do bem arrendado, ou seja, a disponibilidade do bem, neste tipo de operação, permanece com o arrendador, ou seja, o arrendador permanece sendo o proprietário (dono) do bem objeto do arrendamento mercantil (leasing).

No que concerne ao arrendamento mercantil ou leasing realizado em operações internas do país, a doutrina e a jurisprudencia já se consolidaram no sentido de que não há a incidência do ICM sobre operações de circulação de mercadorias, justamente porque nestas operações não ocorrem a trasnferência de titulariade do bem arrendado, o qual é fundamental para caracterização do critério material da hipótese tributária deste tributo. 
Em artigo da lavra de Ataliba, no qual é analisada a não incidência do ICM nas operações realizadas mediante arrendamento mercantil (leasing), assim restou consignado pelo professor:

Circular significa, para o direito, mudar de titular. Se um bem ou uma mercadoria muda de titular, ocorre circulação para efeitos jurídicos. [...] Vê-se, portanto, que 'circulação', tal como constitucionalmente estabelecido (art. 155, I, 'b’), há de ser jurídica, vale dizer, aquela na qual ocorre a efetiva transmissão dos direitos de disposição sobre mercadoria, de forma tal que o transmitido passe a ter poderes de disposição sobre a coisa (mercadoria). ${ }^{87}$

Nesse sentido, não se materializando a opção de compra do bem pelo arrendatário, não há se falar em incidência de ICM no arrendamento mercantil ou leasing realizado em operações internas, posto que não haverá a transferência do domínio do bem para o patrimônio do arrendatário (inocorre a transferência dos direitos de disponibilidade do bem arrendado para o arrendatário). Portanto, nestes tipo de operação não ocorre a circulação de mercadoria para fins de incidência do ICM.

Este posicionamento resta consolidado pela doutrina e jurisprudência, tanto que a própria Lei Complementar $\mathrm{n}^{\circ} .87 / 96$ prescreveu em seu artigo $3^{\circ}$, inciso VIII, que "o imposto não incide sobre: [...] VIII - operações de arrendamento mercantil, não compreendida a venda do bem ao arrendatário”. Veja-se que, a norma faz a ressalva aos casos em que o bem arrendado é adquirido pelo arrendatário, momento no qual ocorre, de fato, a transferência de titularidade do bem, ou seja, os direitos de disponibilidade do bem, sendo passivel, portanto, de incidêncio do tributo.

Em que pese restar consolidado o entendimento da não incidência do ICM nas operações de arrendamento mercantil realizadas internamente no país, muito se discuste quanto à incidência deste tributo nas operações externas realizadas mediante arrendamento mercantil, ou seja, quando são efetuadas importações mediante este tipo de operação.

Conforme se verificou do tópico anterior, a doutrina se divide em dois posicionamentos distintos quanto à incidência do ICM na importação, por conta de diferentes entendimentos quanto ao critério material da hipótese tributária deste tributo, os quais foram abordados no tópico anteceente (subtópicos 2.1 e 2.2).

Autores como Paulo de Barros Carvalho, Roque Antônio Carrazza, Gabriel Lacerda Troianelli, entre outros, sustentam que o critério material na importação está vinculado à necessidade de transferência de titularidade do bem ou mercadoria importada, devendo esta incidência respeitar a matriz constitucional de incidência do ICM 
(operações de circulação de mercadorias). No entanto, destacou-se também o posicionamento do Professor Marcelo Viana Salomão, o qual sustenta que o ICM na importação, em verdade, seria um novo tributo, possuindo o binômio hipótese tributária/base de cálculo completamente desvinculado do tradicional ICM (incidente sobre operações de circulação de mercadorias), incidindo este tributo pela simples entrada do bem do exterior no país.

A partir daí, já pode se ter uma ideia de como se divide os mencionados doutrinadores, especificamente, em relação à incidência do ICM nas importações realizadas mediante arrendamento mercantil ou leasing.

Para o primeiro entendimento, apenas haverá a incidência do imposto quando se efetivar a opção de compra do bem pelo arrendatário, momento em se concretizaria a transferência da titularidade do bem arrendado. Não se concretizando a opção de compra na importação realizada mediante arrendamento mercantil, esta importação não estará sujeita à incidência do ICM.

De outro lado, para a segundo posicionamento, independentemente do tipo de operação realizada, sempre que se concretizar a simples importação do bem do exterior, esta operação estará sujeita à incidência do ICM (ou o denominado Imposto de Importação Estadual). Ou seja, ocorrendo a simples importação do bem ou mercadoria do exterior, haverá a incidência do ICM, independente desta importação ter sido efetuada mediante arrendamento mercantil ou leasing.

Por óbvio que os estados federados e o distrito federal aplicam o entendimento deste segundo entendimento. Nesse sentido, este entes políticos efetuam a cobrança do tributo em toda e qualquer tipo de operação de importação, independentemente de ocorrer a transferência de titularidade do bem ou mercadoria importada.

A título de conhecimento, traz-se a Consulta n. 109, realizada em 1998, por contribuintes do Estado do Paraná, perante a Fazenda Pública, quanto a este tipo de incidência do ICM. Naquele momento, assim se posicionou o entendimento daquele estado-membro:

1. está correto seu entendimento de que não incide ICMS no contrato internacional de arrendamento mercantil - leasing?

[...]

Do exposto, responde-se negativamente as indagações da consulente em razão de que:

1. a caracterização do fato gerador independe da natureza jurídica da operação que o constitua $\left(\operatorname{art} .2^{\circ}, \S 2^{\circ}\right.$, da $\left.\operatorname{LC~} n^{\circ} 87 / 96 ;[\ldots]\right) .{ }^{88}$

Dez anos após a referida consulta, verifica-se que o entendimento do Fisco Estadual do Paraná permanece inalterado, conforme pode se observar da Consulta $\mathrm{n}^{\circ}$. 21, realizada em 2008: 
A matéria questionada refere-se à incidência do ICMS em operação de importação com contrato de arrendamento mercantil internacional e sob o regime de admissão temporária.

$[\ldots]$

Portanto, respondendo ao questionamento da Consulente, tem-se que a importação por ela realizada está sujeita ao ICMS, devendo ser recolhido o imposto no momento do desembaraço aduaneiro [...]. ${ }^{89}$

Diante deste posicionamento dos Estados Federados e do Distrito Federal, em efetuar a cobrança do tributo em todo e qualquer tipo de importação de bens e mercadorias, tem-se verificado uma batalha no Poder Judiciário, o qual ainda não se posicionou de maneira consolidada sobre o tema, conforme será abordadona sequência (tópico 4).

Não obstante, pedimos vênia para demonstrar o posicionamento pessoal adotado sobre o tema, após análise dos diferentes posicionamentos da doutrina quanto à esta matéria, realizada através do presente trabalho. Nesse aspecto, seguimos o entendimento dos Professores Paulo de Barros Carvalho, Roque Antônio Carrazza, Gabriel Lacerda Troianelli, exposto no tópico anterior (subtópico 3.1), segundo o qual, para que haja a incidência do ICM na importação, deve-se ocorrer a transferência de titularidade do bem ou mercadoria importada do exterior, pois esta incidência é vinculada ao critério material da hipótese tributária do ICM incidente sobre operações de circulação de mercadorias.

Para demonstrar de forma efetiva este posicionamento, deve-se realizar uma interpretação sistemática, e não apenas literal, do dispositivo constitucional que autoriza a instituição do ICM pelos estados federados e pelo distrito federal, a fim de melhor entender a sua incidência.

Importante restar consignado que em nenhum momento a Constituição Federal outorga, mesmo em sua redação original de 1988, competência para que os estados federados e o distrito federal instituam imposto sobre a simples importação de bens ou mercadorias do exterior.

A constituição federal outorga competência apenas para os estados federados e o distrito federal instituirem impostos sobre os eventos descritos nos incisos I, II, e III, do seu artigo 155. 90 As disposições trazidas nos parágrafos deste artigo devem ser entendidas como complementos destes eventos, e ainda, como diretrizes e princípios norteadores da incidência destes tributos, mas não como sendo um novo tipo de incidência.

Dessa maneira, o $\S 2^{\circ}$, inciso IX, alínea $a$ do artigo $155^{91}$, deve ser interpretado como um complemento ao inciso II, do mesmo artigo, mas não como uma outorga do legislador constituinte para instituição de impostos sobre a importação.

Importante mencionar que o $\S 2^{\circ}$, inciso IX, alínea a do artigo 155 foi trazido à Constituição Federal (conforme mencionado, através de uma grande pressão política 
exercida pelos Estados) como forma de alargar, ou seja, aumentar, majorar a incidência do ICM, para que este tributo também alcance as operações de importação.

Em vista disto que o legislador constituinte trouxe a expressão: "§ $2^{\circ}$ - O imposto previsto no inciso II [...] IX - incidirá também”. Ou seja, o termo “incidirá também" apenas demonstra o intuíto do legislador constituinte em alargar a incidência do tributo, mas não de instituir um novo tributo, de competência dos Estados Federados e do Distrito Federal, incidente sobre a importação. Até porque, o legislador constituinte já havia outorgado à União Federal, diga-se, acertadamente, a competência para a instituição de imposto sobre estas operações (importação) - art. 153, inciso I, da Constituição Federal. ${ }^{92}$

Quanto à inclusão da incidência do tributo não apenas sobre mercadorias, mas sobre todo e qualquer tipo de bem, destaca-se que esta é mais uma demonstração da intenção do legislador constituinte em alargar a incidência do ICM, ainda que de forma restrita à operações de importação.

Outra demonstração da verdadeira intenção do legislador constituinte em aumentar a incidência do ICM para abranger as importações, também pode ser verificada pela expressão "ainda que as operações e as prestações se iniciem no exterior". Em que pese a discussão quanto à impossilidade de se tributar um operação que não tenha ocorrido dentro do território do Estado, conforme muito bem fundamentado pelo Professor Marcelo Viana Salomão, esta expressão claramente demonstra a inteção de se alargar a tributação do ICM para seja alcançada as operações de importação.

Por fim, entendo que não se pode considerar que o ICM incide sobre toda e qualquer tipo de importação, independentemente da natureza da operação, pois esta é uma competência outorgada, exclusivamente, à União Federal, conforme dispõe o seu artigo 153 , inciso I.

Não merece prosperar o entendimento de que esta incidência seria possível, pois decorrem do mesmo poder constituinte originário. Primeiro, porque, impossível admitir que um mesmo evento seja tributado por entes federativos distintos (União e Estados Federados/Distrito Federal). E, depois, se assim o quisesse o legislador constituinte, este teria previsto o evento importação no rol de impostos descritos nos incisos do artigo 155, da Constituição Federal.

Diante disso, acompanho o posicionamento dos professores Paulo de Barros Carvalho, Roque Antônio Carrazza, Gabriel Lacerda Troianelli, exposto no subtópico 2.1, entendendo que somente nos casos em que ocorra a transferência de titularidade do bem importado é que há exigência do ICM na importação, pois esta incidência deve estar vinculada ao critério material da hipótese tributária do tradicional ICM, a qual se dá apenas sobre operações de circulação.

Quanto às importações realizadas mediante arrendamento mercantil ou leasing, objeto do presente estudo, pode se dizer que penas haverá a incidência do imposto quando se efetivar a opção de compra do bem pelo arrendatário, momento em que se 
concretizaria a transferência da titularidade do bem arrendado. Não se concretizando a opção de compra na importação realizada mediante arrendamento mercantil, esta importação não estará sujeita à incidência do ICM.

Corroborando este posicionamento, traz-se a doutrina do Professor Roque Antonio Carrazza sobre a incidência do ICM na importação mediante arrendamento mercantil:

\begin{abstract}
Reiteramos (v. supra, subitem 2.7.2) que, apesar da EC 33/2001 "permitir” que o ICMS incida "sobre a entrada de bem ou mercadoria importados do exterior por pessoa física ou jurídica, ainda que não seja contribuinte habitual do imposto, qualquer que seja sua finalidade”, o arrendamento mercantil efetuado no exterior passa ao largo deste tributo, por não se encaixar em sua regra-matriz constitucional, originariamente traçada. ${ }^{93}$
\end{abstract}

Seguindo esse entendimento, o autor também destaca que a não tributação pelo ICM do arrenda mercantil ocorrido internamente no país, mas somente operações externas, de importação mediante este tipo de operação, estar-se-ia infringindo o princípio da isonomia, consagrado pela Constituição Federal: "como se isto não bastasse, o próprio princípio da igualdade milita no sentido da não-incidência. De fato, seria anti-isonômico tributar apenas o arrendamento mercantil efetuado no exterior”.

Diante das fundamentações acima expostas, acompanhadas pelo forte entendimento dos doutrinadores mencionados anteriormente no subtópico 2.1, pode-se afirmar, que a incidência do ICM nas operações de importação mediante arrendamento mercantil apenas ocorre quando se efetivar a opção de compra do bem pelo arrendatário, momento em se concretizaria a transferência da titularidade do bem arrendado. Isto porque, o ICM incidente na importação deve estar vinculado à regra matriz de incidência fiscal deste tributo, a qual, no critério material da hipótese tributária, preve a necessidade de transferência de titularidade do bem ou mercadoria.

\title{
4 A Interpretação dos tribunais superiores
}

Como se verificou no tópico anterior, após a previsão contitucional da possibilidade da incidência do ICM nas importações, o que se deu através do alargamento hipótese tributária deste tributo, os estados federados e o distrito federal passaram a exigir o recolhimento do ICM sobre toda e qualquer importação, independentemente do tipo de operação em que esta operação ocorresse.

Diante disso, todas aquelas pessoas que importam bens ou mercadorias do exterior, independente de como esta importação se efetivasse, foram sujeitadas ao pagamento deste tributo, ainda que ausente o requisito de transferência de titularidade do produto importado, como ocorre no arrendamento mercantil ou leasing, acima descrito. 
Esta cobrança, todavia, afronta diretamente a constituição federal, pois viola a regra matriz de incidência fiscal deste tributo, prevista na norma fundamental do ordenamento jurídico pátrio. Nesse aspecto, a matriz constitucional do ICM na importação exige, para a efetivação de sua incidência, que na operação (negócio jurídico) realizada ocorra a transferência de titularidade do bem ou mercadoria importados do exterior.

Tendo em vista esta flagrante inconstitucionalidade, bem como o fato dos estados federados e o distrito federal insistirem na cobrança do tributo em toda e qualquer operação de importação, independente de haver a transeferência da titularidade dos produtos importados do exterior, a presente discussão foi levada à análise do poder judiciário.

Nesse aspecto, importante trazer à colação o julgamento da matéria realizada pelo Plenário do Supremo Tribunal Federal, através do Recurso Extraordinário $\mathrm{n}^{\circ}$. 206.069/SP, publicada em $1^{\circ}$ de setemro de 2006, cuja discussão envolve a incidência do ICM sobre uma operação de importação realizada mediante arrendamento mercantil ou leasing.

A Ministra Ellen Gracie, Relatora do mencionado recurso, analisando esta matéria consignou que a importação, independente do tipo deoperação realizada, está sujeita à incidência do tributo.

Assim constou do voto da Ministra Ellen Gracie:

A Constituição Federal elegeu o elemento fático "entrada de mercadoria importada" como caracterizador da circulação jurídica da mercadoria ou do bem, e dispensou indagações acerca dos contornos do negócio jurídico realizado no exterior.

Veja-se que, a par de incidir sobre "operações relativas à circulação de mercadorias”, fez o Constituinte de 1988 constar do Texto Constitucional a expressa ressalva da incidência sobre "a entrada" do bem importado.

Como se vê, restou consignado neste julgado, no entendimento da Ministra Relatora, que não é relevante o tipo de operação em que se efetiva a importação do bem ou mercaoria do exterior, devendo incidir o ICM sobre toda e qualquer tipo de importação, ainda que não ocorra a transferência de titularidade do produto importado.

Não obstante, de todo equivocado este entendimento, pois, conforme explanado anteriormente, este tributo só poderá incidir sobre operações de importação em que ocorram a transferência de titularidade do bem ou mercadoria importada do exterior, pois deve-se observar a matriz constitucional de incidência deste tributo.

Importante destacar, ainda, um equívoco no entendimento exarado pela relatora, pois esta considera como sendo o critério material do tributo a expressão "entrada de 
bem ou mercadoria importada", contudo, conforme já estudado, esta expressão se refere, de acordo com o entedimento de grande parte da doutrina, ao critério temporal da hipótese tributária do ICM sobre as operações de importação.

Vale ressaltar que, no julgado acima, os produtos importados passariam a compor, ao final do contrato, o patrimônio do importador, momento em que ocorreria a transferência de titularidade dos produtos importados. Contudo, esta não foi a razão fundamental que consubstanciou a decisão da ministra relatora. Ademais, importante que se diga, ainda nestes casos, apenas ocorrerá a incidência do tributo quando se concretizar a opção de compra do produto pelo importador do bem, não pela mera previsão contratual da destinação do produto.

Continuando a análise do entendimento dos Tribunais Superiores sobre este tema, importante mencionar um segundo julgado do Plenário do Supremo Tribunal Federal, qual seja, o Recurso Extraordinário nº 461.968/SP, publicado em 24 de agosto de 2007, de relatoria do Ministro Eros Grau, em que se analisava a incidência do ICM sobre a importação de uma aeronave, realizada mediante arrendamento mercantil ou leasing.

Assim, restou consignado no voto do Relator Ministro Eros Grau:

10. O imposto não é sobre a entrada de bem ou mercadoria importada, senão sobre essas entradas desde que elas sejam atinentes a operações relativas à circulação desses mesmos bens ou mercadorias.

11. Digo-o em outros termos: o inciso XI, alínea a, do $\S 2^{\circ}$ do artigo 155 da Constituição do Brasil não instituiu um imposto sobre a entrada de bem ou mercadoria importadas do exterior por pessoa física ou jurídica.

12. O que faz é simplesmente estabelecer que, desde que atinente a operação relativa a sua circulação, a entrada de bem ou mercadoria importadas do exterior por pessoa física ou jurídica sofrerá a incidência do ICMS.

13. Daí porque o tributo não incide sobre a importação de aeronaves, equipamentos e peças mediante contrato de arrendamento mercantil (leasing) a que respeita o recurso extraordinário.

[...]

Nego provimento ao recurso extraordinário do Estado de São Paulo, para julgar indevida a incidência do ICMS sobre a importação de equipamentos em virtude de arrendamento mercantil contratado pela indústria aeronáutica de grande porte para viabilizar o uso, pelas companhias de navegação aérea nacionais, de aeronaves por ela construídas e julgo prejudicado o recurso extraordinário da TAM - Linhas Aéreas S.A.

Conforme pode se observar, já no entendimento do Ministro Eros Grau, somente será possível a incidência do tributo nas operações de importação em que ocorram 
a transferência de titularidade do bem importado do exterior, não incidindo o ICM, portanto, nos casos de operações de importação realizadas mediante arrendamento mercantil ou leasing.

Quanto à dissonância de entendimentos deste julgado para o anterior, de relatoria da Ministra Ellen Gracie, assim se manifestou o Ministro Eros Grau:

E nem se alegue que se aplica ao caso o precedente do RE ${ }^{\circ} .206 .069$, Relatora a Ministra Ellen Gracie, no bojo do qual se verificava a circulação mercantil, pressuposto da incidência do ICMS. Nesse caso, aliás, acompanhei a relatora. Mas o precedente disse com a importação de equipamento destinado ao ativo fixo da empresa, situação na qual a opção do arrendatário pela compra do bem ao arrendador era mesmo necessária, como salientou a eminente relatora.

Pode-se observar, diante destes dois julgados sobre o tema, que o entendimento da Corte Suprema caminha no sentido de que o ICM apenas incidirá sobre operações de importação em que se efetive a transferência de titularidade do bem ou mercadoria importadada, o que não se dá através do arrendamento mercantil ou leasing, salvo nos casos em que se concretiza a opção de compra pela arrendatário.

Corroborando o entendimento do Supremo Tribunal Federal, importante trazer o posicionamento exarado pelo Superior Tribunal de Justiça, que também aplica a incidência do tributo sobre a importação apenas nos casos de transferência e titularidade do produto importado.

Dessa maneira, traz-se à baila as seguintes ementas de decisões o Superior Tribunal de Justiça:

\section{TRIBUTÁRIO - ARRENDAMENTO MERCANTIL - LEASING - DESCARACTERIZAÇÃO DO CONTRATO - ICMS - INCIDÊNCIA NA IMPORTAÇÃO DE BENS EM REGIME DE LEASING - PRECEDENTES. \\ $[\ldots]$ \\ 4. Posição remansosa desta Corte, em vários precedentes, quanto à não-incidência de ICMS na importação de bem sob a modalidade de leasing. \\ 5. Recurso especial improvido. ${ }^{94}$ \\ IMPORTAÇÃO DE AERONAVE PELO REGIME DE LEASING. ICMS. NÃO INCIDÊNCIA. ALTERAÇÃO DO ART. 155, § $2^{\circ}$, “a” DA CF PELA EMC 33/2001. MANUTENÇÃO DO ENTENDIMENTO. PRECEDENTE DA PRIMEIRA SEÇÃO.}

I - A jurisprudência desta Corte sedimentou-se no sentido de que não incide ICMS sobre a importação sob regime de leasing. Precedentes:

REsp n ${ }^{\circ}$. 341.423/SP, Rel. Min. ELIANA CALMON, DJ de 18/02/2002, REsp n ${ }^{\circ}$. 299.674/SP, Rel. Min. GARCIA VIEIRA, DJ de 11/06/2001; REsp nº. 58.376/SP, 
Rel. Min. HUMBERTO GOMES DE BARROS, DJ de 08/05/95.[...]

III - Mesmo após a alteração que a EC 33/2001 promoveu no art. 155, § 2. o, "a”, da Constituição da República, tem-se que nos contratos de leasing, por não existir a circulação jurídica da mercadoria, não incide o ICMS. A propriedade do bem permanece com o arrendante, sendo que a mera circulação física da mercadoria não configura o fato gerador daquele tributo.

IV - [...] De qualquer forma, os bens assim importados não integrarão o ativo fixo do importador, não havendo que se falar em circulação de mercadoria.

$\mathrm{V}$ - Agravo regimental improvido. ${ }^{95}$

RECURSO ESPECIAL. TRIBUTÁRIO. IMPORTAÇÃO DE PEÇAS DE REPOSIÇÃO DE AVIÃO. ARRENDAMENTO MERCANTIL. NÃO INCIDÊNCIA DE ICMS. PRECEDENTES.

'A jurisprudência desta eg. Corte é iterativa, no sentido de que a importação de mercadorias mediante contrato de arrendamento mercantil (leasing) não caracteriza fato gerador do ICMS' (AGA n. 343.438/MG, Rel. Min. Peçanha Martins, DJ de 30.06.2003).

Na vigência do arrendamento, a titularidade do bem arrendado é do arrendante, admitida a sua transferência futura ao arrendatário. Não há, até o término do contrato, transmissão de domínio, razão pela qual se entende que não existiu circulação do bem para fins de cobrança do ICMS. Nesse diapasão, estabelece o artigo $3^{\circ}$, inciso VIII, da Lei Complementar n. 87/96 que o imposto não incide sobre operações de arrendamento mercantil, não compreendida a venda do bem arrendado ao arrendatário.

Recurso especial provido. ${ }^{96}$

No mesmo sentido são os seguintes julgados do Superior Tribunal de Justiça: REsp n. 239.331/SP, Rel. Min. Franciulli Netto, DJ de 02.06.2003; REsp n. 439.884/SP, Rel. Min. Luiz Fux, DJ de 02.12.2002; REsp n. 299.674/SP, Rel. Min. Garcia Vieira, DJ de 11.06.2001; REsp n. 58.376/SP, Rel. Min. Humberto Gomes de Barros, DJ de 08.05.95, entre outros.

Diante do que foi exposto, pode-se concluir que o entendimento dos Tribunais Superiores que analisam diretamente esta matéria encontra-se em consonância com o disposto no presente trabalho, no sentido de que o ICM incidente sobre operações de importação deve respeitar a matriz constitucional deste tributo, a qual prevê a necessiadade de transferência de titularidade dos bens ou mercadorias importadas. Não há, portanto, a incidência do tributo nos casos de importação realizada mendiante arrendamento mercantil ou leasing, pois inocorre, nestes casos, a transferência de titularidade dos produtos importados. 


\section{Conclusão}

Por meio do presente trabalho, pode-se verificar que para a exigência do ICM nas operações de importações é imprescindível que ocorra a transferência de titulariade do bem ou mercadoria importada. Nesse aspecto, a transferência de titularidade é compreendida como a modificação da pessoa que possui a disponibilidade sobre o mencionado bem ou mercadoria.

Tal exigência se faz necessária, pois a incidência do tributo neste tipo de operação (importação) permanece vinculado à regra matriz de incidência fiscal do ICM, mais precisamente ao critério material da hipótese tributária deste tributo, que é identificado como operações de circulação de mercadorias, as quais, no caso de operações de importação, referem-se não só a mercadorias, mas também a qualquer tipo de bem.

Conforme foi observado, grande maioria da doutrina possui este entendimento, todavia, destacou-se a existência de uma corrente doutrinária que defende a incidência do ICM sobre toda e qualquer tipo de entrada de mercadoria ou bem do exterior, independentemento do tipo de negócio jurídico em que se efetivou a importação. Para esta corrente, o ICM na importação seria um novo imposto de competência do estados federados e do distrito federal, preferencialmente denominado de Imposto de Importação Estadual.

Não obstante, o posicionamento adotado no presente estudo foi contrário a esta tese, defendendo a incidência do ICM somente naquelas importações em que se configura a transferência de titularidade do bem ou mercadoria importada do exterior, seguindo o entendimento de grande parte da doutrina.

Nesta fundamentação, destacou-se a ausência de outorga constitucional para osEstados Federados e pelo Distrito Federal instituirem um imposto de importação, sendo que o legislador constituinte pretendeu, tão somente, alargar a incidência do ICM, com afinalidade deste tributo abarcar também as operações de entrada de mercadorias do exterior (importação).

Dessa maneira, no que se refere especificamente às importações realizadas mediante arrendamento mercantil, demonstrou-se que, em regra, não ocorre a incidência do ICM, tendo em vista que se trata de operação onde não há transferência de titularidade do bem arrendado. A incidência do tributo, nesses casos, apenas ocorrerá quando se efetivar a opção de compra do bem pelo arrendatário, pois somente neste momento é que se concretiza a transferência da titularidade do bem importado mediante leasing.

Corroborando o entendimento exarado no presente estudo, a jurisprudência dos Tribunais Superiores (STF e STJ) vem se consolidando quanto à não incidência do ICM nas operações de importações realizadas mediante arrendamento mercantil ou leasing, permitindo a cobrança deste tributo apenas nos casos em que se efetiva a opção de compra do bem pelo arrendatário. Isto porque, o ICM incidente na importação deve estar vinculado à regra matriz de incidência fiscal deste tributo, a qual, no 
critério material da hipótese tributária, preve a necessidade de transferência de titularidade do bem ou mercadoria.

: ARTIGO APROVADO (24/06/2010) : RECEBIDO EM 30/03/2010

\section{NOTAS}

1 O presente estudo é resultado de trabalho de conclusão de curso apresentado ao curso de graduação em direito, da Pontifícia Universidade Católica do Paraná (PUC/PR), como requisito parcial à obtenção do título de bacharel em direito, tendo como professora orientadora a Dra. Marlene Kempfer Bassoli.

2 BOBBIO, Norberto. Teoria da norma jurídica. 2. ed. rev. São Paulo: EDIPRO, 2003. p. 23-24.

3 BOBBIO, Norberto. Teoria do ordenamento jurídico. 10. ed. Brasília: UNB, 1999. p. 33.

4 CARValho, Paulo de Barros. Curso de direito tributário. 15. ed. São Paulo: Saraiva, 2003. p. 247.

5 Ibidem, p. 244-245.

6 Idem. Direito tributário: fundamentos jurídicos da incidência. 2. ed. rev. São Paulo: Saraiva, 1999. p. 10.

7 ATALiBA, Geraldo. Hipótese de incidência tributária. 5. ed. São Paulo: Malheiros, 1996. p. 53.

8 Ibidem, p. 61-62.

9 ATAliBA, Geraldo. Hipótese de incidência tributária. 5. ed. São Paulo: Malheiros, 1996. p. 63.

10 CARVAlHO, Paulo de Barros. Teoria da norma tributária. 4. ed. São Paulo: Max Limonad, 2002. p. 246-247.

11 Ibidem, p. 122-124.

12 CARVAlho, Paulo de Barros. Curso de direito tributário. 15. ed. São Paulo: Saraiva, 2003. p. 253.

13 Idem. Teoria da norma tributária. 4. ed. São Paulo: Max Limonad, 2002. p. 125.

14 Ibidem, p. 125-126.

15 ATAliBA, Geraldo. Hipótese de incidência tributária. 5. ed. São Paulo: Malheiros, 1996. p. 95.

16 CARVAlHO, op. cit., p. 130.

17 CARVAlhO, Paulo de Barros. Curso de direito tributário. 15. ed. São Paulo: Saraiva, 2003. p. 257.

18 Idem. Teoria da norma tributária. 4. ed. São Paulo: Max Limonad, 2002. p. 134.

19 CARVAlHO, Paulo de Barros. Curso de direito tributário. 15. ed. São Paulo: Saraiva, 2003. p. 260-261. 


\section{6 : O ICM NA IMPORTAÇÃO MEDIANTE ARRENDAMENTO MERCANTIL}

20 ATALIBA, Geraldo. Hipótese de incidência tributária. 5. ed. São Paulo: Malheiros, 1996. p. 85.

21 AMARAL, Francisco. Direito civil: introdução. 4. ed. Rio de Janeiro: Renovar, 2002.

22 CARVAlho, Paulo de Barros. Curso de direito tributário. 15. ed. São Paulo: Saraiva, 2003. p. 281.

23 Idem. Teoria da norma tributária. 4. ed. São Paulo: Max Limonad, 1998. p. 163.

24 ATAliBA, Geraldo. Hipótese de incidência tributária. 5. ed. São Paulo: Malheiros, 1996. p. 55.

25 CARVAlHO, Paulo de Barros. Teoria da norma tributária. 4. ed. São Paulo: Max Limonad, 1998. p. 165.

26 ATALIBA, Geraldo. Hipótese de incidência tributária. 5. ed. São Paulo: Malheiros, 1996. p. 77.

27 CARVALHO, op. cit., p. 165.

28 Idem. Curso de direito tributário. 15. ed. São Paulo: Saraiva, 2003. p. 327.

29 ATALIBA, op. cit., p. 97.

30 CARVAlHO, Paulo de Barros. Teoria da norma tributária. 4. ed. São Paulo: Max Limonad, 1998. p. 177.

31 ATALIBA, Geraldo. Hipótese de incidência tributária. 5. ed. São Paulo: Malheiros, 1996. p. 101.

32 CARRAZZA, Roque Antonio. ICMS. 9. ed. São Paulo: Malheiros, 2003. p. 34-35.

33 Ibidem.

34 SALOMÃO, Marcelo Viana. ICMS na importação. 2. ed. São Paulo: Atlas, 2001. p. 31.

35 AMARAL, Francisco. Direito civil: introdução. 4. ed. Rio de Janeiro: Renovar, 2002. p. 359.

36 MACHADO, Hugo de Brito. Comentários ao código tributário nacional. 1. ed. São Paulo: Atlas, 2003. v. 1. p. 520.

37 ATALIBA, Geraldo; GIARDINO, Cleber. Núcleo da definição constitucional do ICM. Revista de Direito Tributário. 7. ed. São Paulo, v. 25-26, 2004. p. 106.

38 ATALIBA, Geraldo; GIARDINO, Cleber. Núcleo da definição constitucional do ICM. Revista de Direito Tributário. 7. ed. São Paulo, v. 25-26, 2004. p. 104.

39 SALOMÃO, Marcelo Viana. ICMS na importação. 2. ed. São Paulo: Atlas. 2001. p. 32.

40 CARrazZA, Roque Antonio. ICMS. 9. ed. São Paulo: Malheiros, 2003. p. 36.

41 Art. 156. Compete aos Municípios instituir impostos sobre: [...] II - transmissão inter vivos, a qualquer título, por ato oneroso, de bens imóveis, por natureza ou acessão física, e de direitos reais sobre imóveis, exceto os de garantia, bem como cessão de direitos a sua aquisição.

42 Art. 155. Compete aos Estados e ao Distrito Federal instituir impostos sobre: I - transmissão causa mortis e doação, de quaisquer bens ou direitos.

43 CARrazZA, Roque Antonio. ICMS. 9. ed. São Paulo: Malheiros, 2003. p. 41.

44 MACHADO, Hugo de Brito. Comentários ao código tributário nacional. 1. ed. São Paulo: Atlas, 2003. v. 1. p. 522.

45 BALEEIRO, Aliomar. ICM sobre a importação de bens de capital para uso do importador. Revista Forense. Rio de Janeiro, v. 250, abr./jun. 1975. p. 143. 
46 MELO, José Eduardo Soares de. ICMS: teoria e prática. 2. ed. São Paulo: Dialética, 1996. p. 18.

47 CARRAZZA, Roque Antonio. ICMS. 9. ed. São Paulo: Malheiros, 2003. p. 41.

48 SALOMÃO, Marcelo Viana. ICMS na importação. 2. ed. São Paulo: Atlas. 2001. p. 39.

49 MACHADO, Hugo de Brito. Aspectos fundamentais do ICMS. 1. ed. São Paulo: Dialética, 1997. p. 56

50 SALOMÃO, op. cit., p. 39.

51 MELO, José Eduardo Soares de. ICMS: teoria e prática. 2. ed. São Paulo: Dialética, 1996. p. 19.

52 SALOMÃO, Marcelo Viana. ICMS na importação. 2. ed. São Paulo: Atlas. 2001. p. 40.

53 MACHADO, Hugo de Brito. Aspectos fundamentais do ICMS. 1. ed. São Paulo: Dialética, 1997. p. 57.

54 MELO, José Eduardo Soares de. ICMS: teoria e prática. 2. ed. São Paulo: Dialética, 1996. p. 104.

55 CARRAZZA, Roque Antonio. ICMS. 9. ed. São Paulo: Malheiros, 2003. p. 37.

56 Ibidem, p. 71

57 MACHADO, Hugo de Brito. Aspectos fundamentais do ICMS. 1. ed. São Paulo: Dialética, 1997. p. 68.

58 MELO, José Eduardo Soares de. ICMS: teoria e prática. 2. ed. São Paulo: Dialética, 1996. p. 125.

59 Art. 155 [...] $\S 2^{\circ} \mathrm{O}$ imposto previsto no inciso II atenderá ao seguinte: V - é facultado ao Senado Federal: a) estabelecer alíquotas mínimas nas operações internas, mediante resolução de iniciativa de um terço e aprovada pela maioria absoluta de seus membros; b) fixar alíquotas máximas nas mesmas operações para resolver conflito específico que envolva interesse de Estados, mediante resolução de iniciativa da maioria absoluta e aprovada por dois terços de seus membros.

60 CARRAZZA, Roque Antonio. ICMS. 9. ed. São Paulo: Malheiros, 2003. p. 72-73.

61 Art. $155[\ldots] \S 2^{\circ} \mathrm{O}$ imposto previsto no inciso II atenderá ao seguinte: III - poderá ser seletivo, em função da essencialidade das mercadorias e dos serviços.

62 CARRAZZA, Roque Antonio. ICMS. 9. ed. São Paulo: Malheiros, 2003. p. 59.

63 MENDONÇA, J. X. Carvalho de. Tratado de direito comercial brasileiro. 7. ed. Rio de Janeiro: Freitas Bastos, 1963. v. 1. p. 261 .

64 MACHADO, Hugo de Brito. Aspectos fundamentais do ICMS. 1. ed. São Paulo: Dialética, 1997. p. 57.

65 SALOMÃO, Marcelo Viana. ICMS na importação. 2. ed. São Paulo: Atlas. 2001. p. 73.

66 Art. 12. Considera-se ocorrido o fato gerador do imposto no momento:

[...] IX - do desembaraço aduaneiro de mercadorias ou bens importados do exterior; (Redação dada pela Lcp 114, de 16.12.2002).

67 MACHADO, Hugo de Brito. Aspectos fundamentais do ICMS. 1. ed. São Paulo: Dialética, 1997. p. 52.

68 MELO, José Eduardo Soares de. ICMS: teoria e prática. 2. ed. São Paulo: Dialética, 1996. p. 42.

69 CARRAZZA, Roque Antonio. ICMS. 9. ed. São Paulo: Malheiros, 2003. p. 57.

70 MACHADO, op. cit., p. 57. 


\section{8}

71 MELO, José Eduardo Soares de. A importação no direito tributário: impostos, taxas, contribuições. 1. ed. São Paulo: Revista dos Tribunais, 2003. p. 121.

72 Ibidem, p. 125.

73 CARRAZZA, Roque Antonio. ICMS. 9. ed. São Paulo: Malheiros, 2003. p. 58.

74 MACHADO, Hugo de Brito. Aspectos fundamentais do ICMS. 1. ed. São Paulo: Dialética, 1997. p. 71.

75 SALOMÃO, Marcelo Viana. ICMS na importação. 2. ed. São Paulo: Atlas. 2001. p. 58.

76 CARRAZZA, Roque Antonio. ICMS. 9. ed. São Paulo: Malheiros, 2003. p. 58.

77 Ibidem, p. 57.

78 CARVALHO, Paulo de Barros. Parecer sobre ICMS: importação e as modificações legislativas perpetradas pela Emenda Consitucional n. 33/01. São Paulo. Trabalho não publicado. p. 11.

79 LEÃO, Cristiano Maciel Carneiro. A emenda constitucional 33/01 e o "novo” ICMS: importação. 2007.163 f. Dissertação (Mestrado em Direito) - Pontifícia Universidade Católica de São Paulo, São Paulo, 2007. p. 136.

80 TROIANELLI, Gabriel Lacerda. A emenda constitucional 33/01 e o ICMS incidente sobre a importação de bens. ICMS e a EC 33. In: ROCHA, Valdir de Oliveira. O ICMS e a EC 33. São Paulo: Dialética, 2002. p. 91.

81 SALOMÃO, Marcelo Viana. ICMS na importação. 2. ed. São Paulo: Atlas. 2001.

82 MÉLEGA, Luiz. O leasing e o sistema tributário brasileiro. São Paulo: Saraiva, 1975. p. 1.

83 MURTA, Roberto de Oliveira. Contratos em comércio exterior. 2. ed. São Paulo: Aduaneiras, 1998. p. 79.

84 WALD, Arnold. A introdução do leasing no Brasil. Revista dos Tribunais. São Paulo, v. 415/10. [s.d.]. p. 12.

85 DINIZ, Maria Helena. Dicionário jurídico: vol. II. São Paulo: Saraiva, 1998. p. 69

86 MÉLEGA, Luiz. O leasing e o sistema tributário brasileiro. São Paulo: Saraiva, 1975. p. 5-6.

87 ATALIBA, Geraldo. ICMS: incorporação ao ativo: empresa que loca, oferece em 'leasing' seus produtos: descabimento do ICMS. Revista de Direito Tributário. São Paulo, v. 52, abr./jun. 1990. p. 74.

88 BRASIL. Secretaria de Estado da Fazenda. ICMS. Incidência. Importação. Leasing: contrato internacional de arrendamento mercantil. Consulta n. 109, de 14 de setembro de 1998. Ultra-Scan Centro de Procedimentos Ecográficos Ltda. Relator: Antonio Spolador Junior.

89 BRASIL. Secretaria de Estado da Fazenda. ICMS. Importação de equipamento. Arrendamento mercantil e admissão temporária. Incidência. Consulta n. 21, de 14 de fevereiro de 2008. PFT - Paranaguá Terminais de Produtos Florestais Ltda. Relatora: Elizete Crispim Carvalho Dias.

90 Art. 155. Compete aos Estados e ao Distrito Federal instituir impostos sobre: I - transmissão causa mortis e doação, de quaisquer bens ou direitos; II - operações relativas à circulação de mercadorias e sobre prestações de serviços de transporte interestadual e intermunicipal e de comunicação, ainda que as operações e as prestações se iniciem no exterior; III - propriedade de veículos automotores.

91 Art. $155[\ldots] \S 2^{\circ} \mathrm{O}$ imposto previsto no inciso II atenderá ao seguinte: [...] IX - incidirá também: a) sobre a entrada de bem ou mercadoria importados do exterior por pessoa física ou jurídica, ainda que não seja contribuinte habitual do imposto, qualquer que seja a sua finalidade, assim como sobre o serviço prestado no exterior, cabendo o imposto ao Estado onde estiver situado o domicílio ou o estabelecimento do destinatário da mercadoria, bem ou serviço. 
92 Art. 153. Compete à União instituir impostos sobre: I - importação de produtos estrangeiros.

93 CARraZZA, Roque Antonio. ICMS. 9. ed. São Paulo: Malheiros, 2003. p. 120.

94 BRASIL. Superior Tribunal de Justiça. Recurso especial improvido n. 692.945/SP. Relatora: Ministra Eliana Calmon. DJ, 11 set. 2006.

95 BRASIL. Superior Tribunal de Justiça. Agravo regimental improvido n. 851386/MG. Relator: Ministro Francisco Galvão. DJ, 01 fev. 2007.

96 BRASIL. Superior Tribunal de Justiça. Recurso especial n. 542.379/SP. Relator: Ministro Franciulli Netto. DJ, 13 out. 2003.

\section{Rafael Brum Silva}

Av. Voluntários da Pátria, n. 364

AdVOGADO

Bairro Andrade - 86061-120

Londrina - PR - Brasil

Graduado em DiReito Pela PontifícIa Universidade rafbrumahotmail.com

Católica do Paraná (PUC/PR) 